\title{
Deepwater sedimentation and Cenozoic deformation in the Southern New Caledonia Trough (Northern Zealandia, SW Pacific)
}

\author{
Etienne S. ${ }^{1,2,{ }^{*}}$, Collot Julien ${ }^{2}$, Sutherland R. ${ }^{3}$, Patriat Martin ${ }^{2,4}$, Bache Francois ${ }^{5}$, Rouillard P. ${ }^{1,2}$, \\ Henrys S. ${ }^{5}$, Barker D. ${ }^{5}$, Juan C. ${ }^{1,2}$
}

${ }^{1}$ ADECAL Technopole, ZoNéCo Research Program, Nouméa, New Caledonia

${ }^{2}$ Geological Survey of New Caledonia, DIMENC, BP 465, 98845 Nouméa, New Caledonia

${ }^{3}$ Victoria University of Wellington, PO Box 600, Wellington, New Zealand

${ }^{4}$ Ifremer, BP70, 29280 Plouzané, France

${ }^{5}$ GNS Science, PO Box 30-368, Lower Hutt, New Zealand

*Corresponding author: S. Etienne, email address : samuel.etienne@gouv.nc

\begin{abstract}
:
The New Caledonia Trough (NCT) is a 2000-3000 m deep bathymetric feature that extends $2500 \mathrm{~km}$ from Taranaki, New Zealand, to the western margin of New Caledonia (Northern Zealandia, SW Pacific). The underlying sedimentary basin originates from Cretaceous extension, but underwent a significant Eocene tectonic event that shaped its present physiography. We present an analysis of the basin based on multibeam data, seismic profiles and rock samples collected on the TAN1312 and TAN1409 Expeditions onboard R/V Tangaroa, combined with legacy data. We focus on the southern part of the basin, where new data reveal a link between compressive deformation of Paleocene strata and their potential reworking into the basin. On the western basin side, Upper Cretaceous to Paleocene strata were deformed by local reverse faults and folds that created a sub-circular bathymetric ridge and seabed exposure. This folded unit (seismic Unit 2) is sharply overlain by a restricted interval imaged as chaotic high-amplitude reflections that are interpreted as syntectonic mass-transport deposits due to slope oversteepening (seismic Unit $1 \mathrm{~b}$ ). This unit is stratigraphically below the main basin onlap surface and seismic mapping revealed that it rapidly thins away from the mouth of a present day submarine canyon imaged on the western slope of the basin, and that is diverted by exposures of Unit 2 deformed strata. Deformed and syntectonic intervals are in turn overlain by a flat-lying unit (seismic Unit 1a) we interpret as reflecting a passive basin fill. Our new data provide insight into an extensive deep-water basin that is remote from terrigenous sediment sources, and new constraints on its Cenozoic tectonic history. Stratigraphic ages are constrained by seismic ties to Taranaki basin petroleum wells and biostratigraphic dating of dredged samples. This specific site has particular significance for understanding tectonic events in the southwest Pacific. Indeed, our observations show that deformation is younger than the Paleocene and is envisaged to be a local expression of a widespread Cenozoic compressive event (called "TECTA", Tectonic Event of the Cenozoic in the Tasman Area), which affected the region after the Mesozoic rifting. On a regional perspective, this study provides new insights on the evolution of the submerged Zealandia continent and associated geodynamic processes such as
\end{abstract}


Gondwana break-up and initiation of the Tonga-Kermadec subduction.

\section{Highlights}

- We present a surface and seismic analysis of the Southern New Caledonia Trough. Basin margins show Cenozoic compressive features and mass transport deposits. A prominent present-day submarine canyon is possibly inherited from this event.

Keywords : Zealandia, New Caledonia Trough, Deepwater basin, Syn-tectonic deposition, Submarine canyon, Sediment waves 


\section{Introduction}

The New Caledonia Trough (NCT) is an extensive (>2000 km long, $>300 \mathrm{~km}$ across)

48 deep-water basin that is remote from terrigenous sediment sources. The southern shallow-

49 water termination of the NCT physiographic trough is called Taranaki Basin, where there are

50 many exploration wells. However, there is relatively sparse seismic data and almost no

51 borehole information in the rest of the NCT (Fig. 1). There is no established lithostratigraphy

52 for the NCT, and scarce data on the sedimentary processes controlling its infill. Based on the

53 interpretation of geophysical data in the broader Tasman Frontier area, a regional-scale

54 seismic-stratigraphic framework has been proposed (Bache et al., 2014a), and tectonic

55 models identify Cretaceous rifting followed by a profound Paleogene tectonic event that

56 included Tonga-Kermadec subduction initiation (Collot et al., 2008, Collot et al., 2009; 
Sutherland et al. 2010; Sutherland et al., 2012; Bache et al., 2012; Bache et al., 2014a; Sutherland et al., 2017). Eocene tectonic processes may have created the present physiography, caused uplift of surrounding ridges, and subsidence of the NCT (Sutherland et al., 2010). Widespread contraction that involved only a small amount of shortening accompanied this event (Sutherland et al., 2017). The detailed timing of events and nature of tectonic processes remains largely unknown. There has been scarce analyses of the sedimentary architecture of this vast sedimentary basin. Late Eocene wave-cut planation surfaces on the Reinga and West Norfolk ridges have been linked with Reinga Basin depocenters (Bache et al., 2014b), but evidence for Paleogene syntectonic deposition remains undocumented within the NCT (Fig. 1). In this study, bathymetric, seismic and dredge sample data are used to characterise stratal relationships that will ultimately bring new insights onto how and when basin formation, deformation, erosion, and deposition occurred. Our study provides a framework for understanding a deepwater basin which does not follow classical rifting models, notably in terms of subsidence history and physical properties of the crust (Baur et al., 2014; Hackney et al., 2012, Sutherland et al., 2010). The understanding of this basin is also significant in the wider atypical context of the Zealandia continent, considered as a unique geodynamic end member being the youngest, thinnest and mostly submerged of all earth continents (Mortimer et al., 2017a).

\section{Regional settings and background studies}

\subsection{Tectono-stratigraphy of the SW Pacific}

The NCT is part of the Tasman Frontier area in the southwest Pacific (Fig. 1), and is closely related to the Mesozoic-Cenozoic geodynamic evolution of the Gondwana and Zealandia continents. Details of the Paleogene tectonic history are still debated (see the recent review of Matthews et al., 2015), but there is general agreement on the main tectonic phases. Eastern Gondwana was bounded by an active margin near Norfolk Ridge, where the Pacific Plate was subducted towards the southwest (present day frame of reference) during Triassic to Early Cretaceous times (Sutherland, 1999; Mortimer et al., 2008). During the Late 
Cretaceous (from ca. $100 \mathrm{Ma}$ ), continental extension of the eastern Gondwana margin occurred (Gaina et al., 1998) and was associated with intracontinental asymmetric rifting to create the Tasman Sea basin (Lister et al., 1991). Continental ribbons formed ridges such as the Lord Howe Rise and Challenger Plateau (Fig. 1). By ca. $83 \mathrm{Ma}$, extension resulted in lithospheric breakup and ocean crust formation in the Tasman Sea (Burns and Andrews, 1973; Uruski and Wood, 1991; Gaina et al., 1998; Sutherland, 1999). Rifting isolated a significant continental fragment of Gondwana, which is now called Zealandia (Luyendik, 1995; Mortimer, 2008, Mortimer et al., 2017a).

Seafloor spreading in the Tasman Sea ceased at around 52 Ma (Gaina et al., 1998), signaling a new Paleogene compressive regime in the northern Tasman Sea. South of New Zealand, seafloor spreading continued, but was re-organized such that a new rift boundary was created orthogonaly to the extinct Tasman spreading ridge and started splitting southern New Zealand (Sutherland, 1995). Within Zealandia, Eocene-Oligocene unconformities are found in New Zealand and at Deep Sea Drilling Project (DSDP) sites in the Tasman Frontier. Unconformity development has been interpreted as deriving from bottom-current reworking caused by the onset of the Antarctic Circumpolar Current (Kennett et al., 1972; 1975). Alternatively, recent studies provide convincing evidence that this depositional hiatus may have a tectonic origin (Collot et al., 2008; Sutherland et al., 2010, Bache et al., 2012; Baur et al., 2014, Rouillard et al., 2017; Sutherland et al., 2017), and would be associated with the onset of Australia-Pacific plate convergence and Tonga-Kermadec (TK) subduction initiation. This event was called "TECTA" (Tectonic Event of the Cenozoic in the Tasman Area) and is thought to include uplift, ridge erosion, compressive deformation, and tectonic subsidence in the order of $1.5 \mathrm{~km}$ in the NCT (Sutherland et al., 2010; Baur et al., 2014; Sutherland et al., 2017).

Following these Paleogene events, most of the region underwent generalised subsidence, from the Oligocene to Recent, with TK subduction roll-back leading to opening of oceanic back-arc basins such as the Norfolk and South Fiji Basin (see Herzer et al., 2011). 
In addition, the Oligocene to Recent time period sees the development of intra-plate volcanism, such as on the Lord Howe Rise (see Van de Beuque et al., 1998; Exon et al., 2004, Mortimer et al., 2010; Mortimer et al., 2017b).

\subsection{The New Caledonia Trough: present-day physiography and origin}

The NCT is a northwest-oriented, $2500 \mathrm{~km}$ long, $300 \mathrm{~km}$ wide bathymetric feature with a depth of 1000 to $3500 \mathrm{~m}$ (Fig. 1). This deep-water basin extends from the western margin of New Caledonia to distal parts of Taranaki Basin in New Zealand. It is bounded by the Fairway Ridge, Lord Howe Rise (LHR), and Challenger Plateau to the west and by the Norfolk and West Norfolk ridges to the east. It was subdivided by Hackney et al. (2012) into northern, central and southern areas, the latter corresponding to the Aotea Basin, which shows clear evidence for Mesozoic rifting (see Collot et al., 2009). The continuity of this physiographic domain, and relatively similar stratigraphic patterns from north to south, suggest a common origin. However, details of the age and formation mechanisms of the NCT remain contentious.

It has been proposed that the NCT physiography is inherited from Late Cretaceous intra-continental rifting, and that the basin has recorded minor or no Cenozoic deformation (Burns and Andrews, 1973; Uruski and Wood, 1991; Lafoy et al., 2005; among others). A more recent hypothesis (Sutherland et al., 2010) considers two tectonic phases: a) a first phase related to Cretaceous rifting that created depocenters across the region, and b) a subsequent phase of anomalous subsidence from Paleogene to Oligocene times, without significant faulting. The latter phase is proposed to have overprinted the earlier phase to produce the large-scale elongate physiography of the NCT. Its mechanism of subsidence is related to convergent plate motions that led to the inception of the Tonga Kermadec subduction (Collot et al., 2008, Collot et al., 2009 Sutherland et al., 2010, Baur et al., 2014, Sutherland et al., 2017). Although this Eocene tectonic event is consistent with regional observations, there is a lack of integrated studies that describe and analyse the erosional products associated with unconformity development. 


\subsection{Regional seismic sequence stratigraphy and stratal relationships}

Seismic stratigraphic units and subunits used in this paper were defined on the basis of the regional-scale seismic sequences defined in Bache et al. (2014a). This stratigraphic framework (Fig. 2), which was also used as the basis for a recent detailed seismicstratigraphic study of the Fairway Basin (Rouillard et al., 2017), comprises three megasequences related to the regional tectonic phases of Zealandia (see previous section): (1) eastern Gondwana active subduction margin (Zealandia Unit 3, Permian to Early Cretaceous); (2) extensional syn-rift to post-rift margin accompanying Gondwana breakup (Zealandia Unit-2, Late Cretaceous to Eocene); and (3) compressive to passive regimes following the onset and roll-back of the TK subduction zone (Zealandia Unit-1, Late Eocene to Recent).

The three regional stratigraphic megasequences are delimited by unconformities (RU2 and RU1 in Bache et al., 2014a). RU2 is an unconformable surface between Unit 3 and Unit 2, and usually truncates Unit 3 strata. It is onlapped by Unit 2 strata and is thought to be of Late Cretaceous age (ca. 105-65 Ma). Unit 2 comprises a syn-rift detrital unit (Unit 2b) followed by a deep-marine post-rift unit (Unit 2a). The upper unconformity (RU1) separates Unit 2 from Unit 1, and corresponds to a regional Eocene-Oligocene hiatus.

This RU1 unconformity corresponds to a depositional hiatus of variable timespan, reaching $35 \mathrm{Ma}$. It is a disconformable surface within basins (typically overlain by flat-lying strata with onlap configuration), and is typically paraconformable on ridges. Its erosional character is subtle on seismic-reflection profiles, but spectacular examples of truncations in folded Paleogene strata have been documented in the Reinga Basin (Bache et al., 2014c; Sutherland et al., 2017), and in the southern LHR close to DSDP sites 207 and 592 (Fig. 1). The inferred detrital products from this tectonically-induced erosional surface form the poorlydated Unit $1 b$, which is a focus of this paper. The top unit, Unit 1a, corresponds to subsidence-related deep-water sediments of Oligocene to Recent age, and is imaged on 
seismic-reflection data as: a) flat-lying undeformed reflections that onlap basin margins, and b) drape units on ridges that have relatively constant thickness (Figs. 3 and 4) .

\section{Data and methods}

This study is primarily based on multi-channel seismic-reflection profiles, multi-beam seafloor bathymetry, backscatter imagery, and dredged rock samples collected in 2013 and 2014, onboard RV Tangaroa, during the TAN1409 and TAN1312 Expeditions.

The TAN1409 Expedition acquired new geophysical data at sites in the Tasman Sea (Sutherland et al., 2014) as a site survey for IODP drilling (Expedition 371, Sutherland et al., 2015). High-resolution multi-channel seismic data were acquired using a 48 channel, $600 \mathrm{~m}$ streamer and a single 45/105 in $^{3}$ Generator Injector air gun operated at 200 psi with shot spacing at $25 \mathrm{~m}$. Processing was done using GNS GLOBE CLARITAS seismic processing software, and data were time migrated using water velocity. Swath bathymetry and backscatter imagery were acquired using a Kongsberg EM302 multibeam echo-sounder.

The TAN1312 Expedition collected multi-beam data with the same EM302 echo sounder, and dredged key stratigraphic units exposed at the seabed in the Reinga and Aotea (southern NCT) basins (Bache et al., 2014c). We use results derived from mineralogical, petrological and paleontological studies on these samples (Browne et al., 2014, Browne et al., 2016). Further details regarding data equipment, acquisition and processing of these expeditions can be found in the corresponding expedition reports (Sutherland et al., 2014; Bache et al., 2014c).

We use data from the Tasman Frontier Geophysical database (Sutherland et al., 2012), which consists of a public compilation of seismic-reflection data from various sources (both industrial and academic) between Australia, New Zealand and New Caledonia (France). We notably use lines from the 114 survey of the Australian Geological Survey Organisation (AGSO, 1992), with technical details of acquisition being available in Marshall et al. (1994). 
Maps provided in this paper were produced using the ArcGis software (ESRI). Seismicreflection data were interpreted using Kingdom Suite software (IHS), using key concepts in seismic sequence stratigraphy (e.g. configuration of seismic reflection terminations, continuity, and inference of unconformities; see Mitchum et al. 1977; Vail et al., 1977; Catuneanu, 2006). Particular attention was given to identifying variability of seismic facies and stratal relationships, to characterise bedform geometries and discuss their origins in terms of sedimentary processes, with implications for syn-sedimentary deformation.

\section{Results}

\subsection{General seismic stratigraphy and structure of the Southern NCT}

This paper focuses on the southern NCT (Fig. 1B, NCTS site of Surtherland et al., 2014), situated on the western slope of the basin, at the base of LHR western margin. In this area, the NCT is slightly narrower than the rest of the trough (120-170 km-wide at its base) and water depths are in the order of $3000 \mathrm{~m}$. The stratigraphic and structural context of the study area is inferred from two parallel northeast-oriented seismic-reflection lines that cross the NCT (lines 114-02 and 114-04; Figs. 3 and 4 respectively), and by a long regional line that follows the basin axis (line TL01; Fig. 5). These lines image the three regional seismic megasequences presented in Section 1.

Seismic Unit 3 corresponds to the acoustic basement and is characterised by chaotic or transparent seismic facies, yet some dipping reflections are locally present. This unit is affected by numerous faults of unknown extension in depth and is potentially bounded at its top by the RU2 regional unconformity.

Seismic Unit 2 is characterised by moderate- to high-amplitude continuous seismic reflections of variable dip. On the western margin of the NCT, normal faults affect Units 2 and 3 on the northern line (114-02, Fig. 3); whereas reverse faults with associated folds in Unit 2 are imaged on the western border of the basin on the southern line (114-04, Fig. 4). Folded and faulted strata are part of a deformed interval described by Collot et al. (2009). 
Deformation affects Unit 3 and Unit 2 along a distance of around $90 \mathrm{~km}$ on the TL01 line (Fig. 5), but the broader extent of deformation is difficult to determine due to the sparse data.

Seismic Unit $1 b$ is characterised by variable moderate- to high-amplitude continuous seismic reflections that either onlap or downlap onto Unit 2. On the eastern margin of the basin, downlap onto a slightly disrupted interval occurs, and is interpreted as prograding sediment wedges derived from subaerial erosion and/or transgressive wave ravinement of the West Norfolk Ridge (Figs. 3 and 4), as evidenced by flat planation surfaces (Sutherland et al. 2010). The overlying Unit $1 \mathrm{a}$ is composed of continuous subhorizontal moderateamplitude reflections that onlap Unit 2 and Unit $1 \mathrm{~b}$ within the NCT, and is a blanket of semicontinuous low-amplitude reflections on the basin flanks. It is interpreted as recording a passive deepwater infill of the basin, accompanied by pelagic drape on the basin flanks. The following sections of this paper focus on the western margin of the basin, where compressive folding occurs and detailed relationships between seismic units and unconformities are revealed by our new dataset.

\subsection{Surface analysis of the NCTS Site}

Detailed morphological analyses of bathymetric and backscatter imagery maps were carried out (Figs. 6 and 7). The maps cover part of the LHR eastern slope over a c. $1700 \mathrm{~km}^{2}$ surface area extending from around $1800 \mathrm{~m}$ to $3000 \mathrm{~m}$ water depth. Here, the most prominent bathymetric feature is a $30 \mathrm{~km}$-long, 2-3 $\mathrm{km}$-wide and up to $250 \mathrm{~m}$-deep submarine canyon that is apparently diverted by a sub-circular bathymetric ridge that is the surface expression of folded Unit 2 strata seen on seismic-reflection profiles (Figs. 4 and 5). The ridge is clearly imaged on backscatter imagery and associated with high reflectivity values that suggest exposure of lithified strata. This was confirmed by the TAN1312 dredge of lithified Paleocene mudstone (Browne et al. 2017).

In an up-dip direction, the submarine canyon terminates at a curved headscarp located close to several highly-reflective small mounds that we interpret as volcanic edifices. A 
volcaniclastic sediment apron is interpreted radially from the largest edifice. In a downdip direction, the low-sinuosity canyon widens at the slope-break towards a canyon mouth area that has a $\sim 10 \mathrm{~m}$ high lobate relief on the present day seafloor (Figs. 6 and 7). We interpret this as a recent canyon-mouth lobe (Fig. 7). On backscatter imagery, both the canyon floor and associated lobe do not show high reflectivity values, which suggest limited present day sediment transport of soft fine-grained material.

Adjacent to the canyon, the slope of the NCT has $50-100$ m-high, and typically 500 mwide (when isolated) topographic escarpments, which we interpret as slope failure scarps (Fig. 7). In some places, they merge to form composite scarps, notably in the southern part of the study area. In addition to these features, the eastern side of the bathymetric ridge diverting the canyon is marked by a series of arcuate, up to c. $150 \mathrm{~m}$-high escarpments with convex shapes facing down the slope ("arcuate escarpments", on Fig. 7). These features are organised into a series of sub-parallel and laterally-discontinuous ridges oriented parallel to the slope that have amplitudes varying from c. 500 to $1000 \mathrm{~m}$. These localised features are relatively well-imaged on the backscatter imagery, with high reflectivity values associated with the crests of the ridges.

There are several scattered volcanic edifices in the area, some of them being associated with linear topographic depressions that we interpret as small gullies caused by sediment gravity flow pathways. The largest of the volcanic features is composed of Oligocene (29 $\pm 2 \mathrm{Ma}$ ) basalt (Mortimer et al. 2017b).

\subsection{Description of seismic units and sub-units}

\subsubsection{Unit 1a}

Unit $1 \mathrm{a}$ is present both on the LHR slope and within the NCT. It forms the uppermost seismic unit in the study area, and its upper boundary corresponds to the seafloor. It comprises two sub-units with distinct seismic characters that are separated by an onlap 
surface: within the NCT we mapped sub-unit $1 a_{1}$; and on the LHR slope we mapped sub-unit $1 a_{2}$.

Sub-unit $1 a_{1}$ is bounded to the west by a basal onlap surface that dips towards the basin (dashed line in Figs. 8, 9 and 10). The sub-unit comprises variable high- to lowamplitude continuous flat-lying parallel reflections. Subtle angular unconformities are interpreted, a character that may be associated with localised erosion. The onlap configuration towards the basin margin causes the stratigraphic thickness of sub-unit $1 a_{1}$ to vary from $1.3 \mathrm{~s}$ twt in the northeastern part of the survey area to a complete pinch-out at the LHR present-day toe-of-slope.

Sub-unit $1 a_{2}$ is restricted to the LHR slope. It is substantially thinner (0-0.4 s twt), and is characterised by variable seismic character and complex geometry, as shown in Figure 11. It is bounded at its base by an irregular surface associated with high-amplitude discontinuous reflections (see section on Unit $1 \mathrm{~b}$ ). Although variable, sub-unit $1 \mathrm{a}_{2}$ typically comprises moderate- to low-amplitude inclined reflections organized into onlapping or downlapping reflections that are tilted updip (towards the west) along the LHR slope (Fig. 11B). However, on seismic lines situated on the eastern flank of the bathymetric ridge that diverts the canyon, sub-unit $1 a_{2}$ comprises complex stacks of undulating to locally contorted reflections, which are developed on the irregular top of Unit $1 \mathrm{~b}$. These geometries are organised into asymmetrical sets with steep and short downslope-dipping flanks and gentler longer upslopedipping flanks (Fig. 12C). Internal reflections are typically parallel to the upslope dipping flank and can be in places traced between sets (Fig. 12C). Additionally dome-shaped, nearly symmetrical geometries are observed (Fig. 12D). In a strike direction, sub-unit $1 \mathrm{a}_{2}$ is marked by wavy geometries accumulated on the depositional dip (Fig. 11C). Apart from these complex features, small erosional features flanked by wedge-shaped geometries are interpreted as leveed gullies (Fig. 10), as observed on the seafloor bathymetry (Fig. 7 and section 3.2).

\subsubsection{Unit 1b}


On the LHR Unit $1 \mathrm{~b}$ is delimited at its base by a surface of truncation (Figs. 4 and 8 ) suggested by reflection toplaps in the underlying Unit. Near the axis of the NCT, this lower surface is paraconformable in most places (Figs. 4 and 5). The upper boundary of Unit $1 \mathrm{~b}$ is irregular and its exact position is hard to define. We define it as the top of discontinuous highamplitude reflections (HARs, figs. 8, 9 and 10).

Unit $1 \mathrm{~b}$ typically comprises seismic reflections with relatively higher amplitude than the other seismic units, with an overall disrupted character. Reflections have low lateral continuity in both dip (Figs. 8 and 9) and strike (Fig. 10) directions. In some places, typically towards the top of the unit, dome-shaped geometries or hyperbolic (concave-up) discontinuous tilted reflections are observed, and there are northeast-dipping reflection packages (i.e. down the depositional dip). The latter are well developed in the northern part of the survey area, where Unit $1 b$ is thickest and is imaged on the seismic line located at the mouth of the present day canyon (Fig. 9).

A general thinning of Unit $1 \mathrm{~b}$ is seen from north (canyon mouth area) to south (folded ridge). Thickness varies from $0.8 \mathrm{~s}$ twt on the northernmost line to less than $0.1 \mathrm{~s}$ twt on the southernmost line (Fig. 13). Because the unit is affected by deformation, stratigraphic correlations between the folded and canyon mouth areas are difficult in the lower part of the unit.

\subsubsection{Unit 2}

The upper part of Unit 2 is imaged on the TAN1409 seismic-reflection profiles. The top boundary is the discontinuous surface at the base of Unit $1 \mathrm{~b}$. The basal bounding surface is not imaged on TAN1409 data, but corresponds to acoustic basement on the 114 and TL01 surveys (Figs. 3, 4 and 5). Unit 2 is composed of moderate- to low-amplitude continuous subparallel reflections that are locally folded and affected by reverse faulting. With the given dataset it is difficult to precisely determine the orientation of the anticline axis that is 
associated with the main fault, but a NNW-SSE direction can be inferred from the combined analysis of seismic-reflection data and the orientation of the bathymetric ridge (Fig. 13).

\section{Interpretation and discussion}

\subsection{Stratal relationships and interpretation of Unit 1}

\subsubsection{Unit 1a: basinal and slope sedimentation}

The seismic character of sub-unit $1 a_{1}$ suggests passive infill of the NCT. The flat seabed of the axial NCT and the strongly-layered internal character of seismic reflectors beneath it, suggest deep-water sedimentation in the form of fine-grained turbidites and hemipelagites or pelagites. The former abruptly pinch out laterally towards bounding slopes. Turbidity flow processes might be responsible for localised erosion in sub-unit $1 a_{1}$, where axial channels and/or lateral lobes rework and entrain older sediment. We suggest that Neogene to presentday axial turbidites in the NCT are primarily sourced from the Taranaki Basin (King and Trasher, 1992; Baur et al, 2010). This is consistent with the continuous gentle slope of the NCT between deep-water Taranaki and DSDP Site 206 (Fig. 1). There was a steady increase in terrigenous sediment supply during the last 20 Ma (King and Trasher, 1992), a character consistent with the increased clay content in the uppermost unit at DSDP 206 (Section 4.2). Subsidiary lateral sediment inputs to the NCT from intra-slope failures on the LHR and Western Norfolk Ridge margins are also significant. In fact, bathymetric data reveal gullies and canyons that feed restricted depositional fans at the base of slope, similar to those imaged on our survey area (Fig. 7).

Sub-unit $1 a_{2}$ has more complex seismic reflection geometry than sub-unit $1 a_{1}$ and is, therefore, more difficult to interpret. Moreover, its boundary with Unit $1 \mathrm{~b}$ and Unit 2 is in places uncertain. A first interpretation would consider that this subunit comprises deep-water slope sediments that represent coeval deposition with sub-unit $1 a_{1}$. In such a scenario, the onlap surface between sub-units $1 \mathrm{a}_{1}$ and $1 \mathrm{a}_{2}$ would correspond to a lateral facies change between basinal and slope deposits (i.e. a pseudo-unconformity rather than a timeequivalent angular unconformity). Axial turbidite deposits of subunit $1 \mathrm{a}_{1}$ would pinch-out 
laterally onto the slope with onlap configuration, whereas slope sedimentation (subunit $1 \mathrm{a}_{2}$ ) would be dominated by aggrading pelagic and hemipelagic fallout complemented by downslope currents. Similar configurations have been described in the ancient rock record (Smith, 2004; Smith and Joseph, 2004) and using seismic data (Badalini et al., 2000). A second interpretation would be to consider that Unit $1 \mathrm{a}_{2}$ does not represent contemporaneous deposits of Unit $1 a_{1}$. In this scenario, subunit $1 a_{2}$ would predate subunit $1 a_{1}$ and be part of Unit 1b (as suggested by Sutherland et al., 2017, their Fig. 2B) or Unit 2. This would imply that, in this particular area, sedimentation rates on the slope are much lower compared to those in the basin, i.e. very few sediments would accumulate on the slope while the basin is being filled. This requires very low sedimentation rates on the slope compared to the axial basin fill and/or significant removal of sediment. Data from DSDP sites on the Lord Howe Rise (DSDP 207-208 and 588-593) reveal 300 to $500 \mathrm{~m}$ of Oligocene to Neogene pelagic ooze sediment cover, therefore, assuming homogeneous background sedimentation, active mechanisms must be involved to prevent sediments from accumulating at such high rates on the slope in our study area. This difference in sedimentation rates between the top of the ridge and the slope could be due to a sustained reworking of sediments by alongslope or downslope currents or, alternatively, sediment removal by gravity induced destabilisations. This is compatible with sub-unit $1 a_{2}$ geometries, notably those in its uppermost intervals (Fig. 12). Such complex geometries, comprising the arcuate escarpment" on surface data and the associated wavy to inclined reflections on seismic data (Figs. 8 and 12), can indeed be explained by either a) deposition of sedimentary bedforms originating from alongslope or downslope flow processes or b) gravity-driven internal deformation (i.e. slow creeps, slides or slumps).

The distinction between slope failure and sediment flow processes as the generation mechanisms for such geometries is known to be difficult and controversial, and there are several examples where submarine landslides have been reinterpreted as migrating sediment waves (see Lee et al., 2002 or Berndt et al., 2006). Furthermore, the types and 
modes of submarine flows at the origin of sediment waves are known to be diverse, and both turbidity currents and bottom currents can generate sediment waves (see Wynn and Stow, 2002; Cartigny et al., 2011; Postma and Cartigny, 2014). In our case, based on the current dataset, distinguishing between these two possible origins is difficult.

On the one hand, the asymmetrical shape of bedforms, thickness variations within reflection sets, the occurrence of internal unconformities, together with the position on an irregular truncation surface could favor deposition from submarine currents. In addition, the downslope orientation of the arcuate escarpments seen on the bathymetry, their dimensions, proximity to an erosional canyon, slope failure scars, and local leveed gullies could also be consistent with the presence of active downslope flow processes on the slope. Furthermore, it is known that irregularity and roughness of seafloor topography can favor sediment wave development through interactions between the flow and the surface beneath (Howe et al., 1998; Ercilla et al., 2002; Cattaneo et al., 2004; Anderskouv et al., 2010; among others). A good candidate for such irregular topography is the upper surface of deformed Unit $1 \mathrm{~b}$. Pushing this former interpretation further, on the basis of morphological parameters (asymmetry, orientation, dimensions) and seismic character, such geometries could be interpreted as originating from down-slope super-critical flows i.e. cyclic steps (sensu Parker, 1996, Fildani et al., 2006 or Cartigny et al., 2014). The observed apparent bedding, which are typically up the depositional dip, are also an additional evidence that could suggest an up-current migration of bedforms generated by super-critical turbidity flows (Symons et al., 2016).

On the other hand, other observations can, in turn, favor the slope creep origin. The geometries seen on seismic-reflection data are not always continuous between each sets, which is a significant criteria to distinguish sediment waves from submarine creep (Lee et al., 2002; Lee and Chough, 2001). This could suggest the presence of small displacement faults or shear planes between creep folds (see the model of Shillington et al., 2012), offsetting reflections and creating bathymetric escarpments on the seafloor. In that sense, the apparent 
dips observed among the whole sub-unit, typically oriented in an upslope direction (Figs. 10 and 11) could suggest a post depositional block tilting rather than an upslope migration of individual deposits. Additionally, strong similarities both in terms of planform geometry and seismic character with recent published examples in the northern South China Sea (He et al., 2014; Li et al., 2016) are compelling, yet our current dataset does not allow to clearly identify the typical component of a slide complex (ie., extensional and compressional zones).

In summary, the existing set of observations do not allow to favor one interpretation, and we also point out the possibility of having a combination of both creep and flow process to explain the complex geometries observed within seismic Unit $1 \mathrm{a}_{2}$. Indeed, it is possible to envisage that the topography generated by creep-features could form the rough and steep seafloor necessary to the development of sediment waves. Lastly, strong deep currents are known to exists in the region, as strongly suggested by the very continuous large scale submarine dunes observed on multibeam data on the crest of the Norfolk and Reinga Ridge (see Fig. 18 of Collot et al., 2016).

\subsubsection{Unit 1b syntectonic unit}

The thickness of Unit $1 \mathrm{~b}$ is greatest close to the mouth of the canyon (Fig. 9 and 11D) and progressively decreases away from it to form a fan-shaped depocenter. Chaotic to downslope oriented geometries are observed within Unit $1 \mathrm{~b}$ near the canyon mouth. Unit $1 \mathrm{~b}$ is unconformable on the deformed Unit 2 and lies beneath the undeformed onlap surface of Unit 1a. The basal strata of Unit $1 \mathrm{~b}$ appear to reflect compressive deformation, which is consistent with the stratigraphic position of Unit $1 \mathrm{~b}$, and are inferred to have been uplifted onto the ridge.

Regarding the lithology of such deposits and their environment of deposition, the highamplitude character of most of the associated reflections is likely to be explained by either bedded heterolithic beds (ie. vertically heterogeneous), possibly related to variable volcanic inputs. We cannot rule out other hypotheses to explain the high-amplitude reflections from 
this unit, such as diagenetic alteration of silica-rich beds (Opal-A/Opal-CT BSR, see Nouzé et al., 2009). Our preferred interpretation in terms of depositional environment, based on seismic character, spatial distribution and information from available nearby DSDP wells (eg. $206,207)$ is that Unit $1 \mathrm{~b}$ corresponds to a relatively restricted mass transport complex or basin floor fan. This interpretation is also supported by the configuration of correlative deposits on the other opposite margin of the basin (Figs. 3 and 4), where Unit $1 \mathrm{~b}$ has clear downlapping and wedge geometries. In addition, given the chaotic complex internal character of Unit $1 \mathrm{~b}$, mass wasting processes must have been involved in the deposition of these packages, and are consistent with renewed tectonic activity and topographic slope creation at the time of deposition of Unit $1 b$.

\subsection{Lithological and stratigraphic constrains}

The only borehole that has sampled and dated the NCT basin fill is DSDP 206 (Burns and Andrews, 1973; Burns et al. 1973; Kennett et al. 1975), which is situated at the northern tip of the Aotea Basin where the NCT narrows to c. $200 \mathrm{~km}$-wide between West Norfolk Ridge and LHR (Fig. 1).

DSDP Site 206 lies at 3196 m water depth on the eastern flank of an elongated bathymetric ridge associated with an acoustic basement high on seismic-reflection data, interpreted as a compressional structure of Late Eocene to middle Oligocene age by Burns et al. (1973). A 734 m-thick succession of bathyal calcareous biogenic oozes was recovered. Four units were distinguished: (i) Early Miocene to Recent unconsolidated nannofossil ooze with foraminifera and minor volcanic ash (0-389 m below sea floor, bsf); (ii) Oligocene to Early Miocene semi-lithified foraminiferal-bearing nannofossil ooze to clay-rich nannofossil ooze (389-614 m bsf); (iii) Middle to Late Eocene slightly deformed and lithified radiolarian-rich nannofossil ooze (614-677 m bsf); and (iv) Early Paleocene to Middle Eocene deformed (slumped to locally inverted) semi-lithified calcareous ooze and clay with minor chert (70-49 Ma; 677-734 m bsf). The regional Eocene-Oligocene unconformity (RU1) is found between units ii and iii, and a Paleocene-Eocene hiatus (unconformity or structural break) is found 
between units iii and iv. Of significance is the increasing clay content in DSDP 206 cores in the Early to Middle Eocene and during the middle Oligocene to Early Miocene, interpreted by Burns et al. (1973) as related to regional tectonic events.

Correlations of lithological units in DSDP 206 with key seismic horizons on seismic data have previously been attempted (e.g. Collot et al., 2009) and facilitated by the TL-01 line that ties DSDP 206 to the Wainui-1 well along the axis of the NCT (Figs. 1 and 5). Eocene and Miocene reflectors can be traced along the axis of the NCT and onto the 114-04 seismic line. Sutherland et al. (2010) correlated the onlap surface of the NCT to the Eocene-Oligocene unconformity and suggested a Middle Eocene to Oligocene age for folding of Unit 2. Bache et al. (2012; 2014a) correlated regional unconformities and units in the NCT and LHR.

Dredge samples were collected by the TAN1312 Expedition (Bache et al., 2014c) from slopes of the sub-circular bathymetric ridge at the NCTS site (Fig. 6). Dredged rocks comprised non-calcareous mudstones, basalt lavas, volcaniclastic hyaloclastite breccias and bedded sandstones (Browne et al., 2016), the latter two rock types being in direct contact in some samples. Petrographic and paleontological analyses were performed on mudstones, whereas petrographic analyses and radiometric dating were performed on basalts (Mortimer et al., 2017). Browne et al. (2016) report palynology determinations on a marine noncalcareous siltstone of Early Teurian age (66-60 Ma; Early Paleocene). This sample originates from the folded Unit 2 (see location on Fig. 6 and projected location on seismic line of Fig. 4). Browne et al. (2016) suggest lithological and age similarities between these mudstones and the Whangai Formation from onshore New Zealand. Mortimer et al. (2017b) provide Ar-Ar groundmass ages of $27.7 \pm 1.2$ and $29.5 \pm 1.5$ (Early to Late Oligocene) on basaltic samples with intraplate geochemical signatures. These volcanic samples may be derived from small mounds (volcanic cones) near the apex of the ridge.

In summary, Unit 2 contains Early Paleocene marine mudrocks, but may range in age from Late Cretaceous to Eocene, and pre-dates regional folding. The erosional surface we observe between Unit 2 and Unit $1 \mathrm{~b}$ could correspond to the regional Eocene unconformity 
(Sutherland et al. 2017). The precise age of Unit $1 \mathrm{~b}$ remains to be determined at the NCTS site. We speculate that Unit $1 \mathrm{~b}$ is composed of reworked pelagic sediment and that it is of Middle to Late Eocene in age. Unit 1a is inferred to have an Oligocene to Recent age and composed of pelagic sediment (nannofossil and foraminifera ooze and chalk) on the basinmargin slopes. Distal turbidites with in situ or reworked pelagic sediment occur near to the NCT axis.

\subsection{Relative timing of deformation and vertical movements}

Sutherland et al. (2010) suggested that the present day physiography of the NCT was primarily formed during Eocene and Oligocene times, which record: (i) 1-2 km of tectonic subsidence along the NCT axis; (ii) uplift and shallow-marine erosion on the NCT flanks (LHR and West Norfolk Ridge); and (iii) subtle tilting, reverse faulting and folding of Late Cretaceous to Paleogene strata. Our study suggests a link between compressive deformation of Unit 2 strata, their syn-tectonic erosion on the western side of the basin, and deposition of Unit $1 \mathrm{~b}$. Unit $1 \mathrm{~b}$ rests on the erosion surface that truncates Unit 2 strata and may be linked with formation and diversion of a submarine canyon, and the unit is overlain by onlapping undeformed Unit 1a strata.

Deformation occurred after the Paleocene and before the deposition of Unit 1a. The nature and origin of Unit $1 \mathrm{~b}$ is key to understanding the relative timing between deformation, topography development, and subsidence of the basin.

A possible interpretation (hypothesis A) would be to consider Unit $1 \mathrm{~b}$ as being deposited during the local deformation of Unit 2 strata, but before the main phase of subsidence of the NCT (fig. 14). This is consistent with the internal seismic character and spatial distribution of Unit $1 \mathrm{~b}$, which is inferred to be a basin-floor fan or mass-transport complex deposited close to the folded structure. In fact, such gravity related deposits could be triggered by increasing topography during deformation and examples of mass-transport deposits related to 
tectonically induced slope oversteepening are numerous (eg Postma et al., 1993; Shillington et al., 2012, see the recent review of Alves, 2015 and references therein).

Alternatively (hypothesis B) one could consider that the complex character of Unit $1 \mathrm{~b}$, as well as the downlapping intervals occurring on the opposite eastern margin (Figs. 3 and 4), records a phase of slope oversteepening and erosion, and therefore the early stages of NCT subsidence. The distribution of Unit $1 b$, which is restricted to the margins of the trough, its chaotic internal character, together with the inferred link to erosional surface on both adjacent ridges, are compatible with the unit being deposited in a setting similar to the present physiography of the basin.

Slope creation at the basin margins, erosion and destabilization is likely to be linked with updip planar erosion surfaces, potentially of subaerial origin, that reflect significant regional changes in base level. However, the origin and age of erosion surfaces remains unadressed. Oligocene capping limestone near the West Norfolk Ridge (Browne et al. 2017) is consistent with the hypothesis that they are linked to deposition of Unit $1 \mathrm{~b}$, which appears to be the earliest infill of the NCT, as suggested by a stratigraphic position below onlap relationships within Unit 1a. Stratigraphic relationships suggest that subsidence responsible for formation of the NCT happened after deposition and deformation of Unit 2 and continued during the early deposition of Unit 1. The whole area, including the LHR and NCT, subsided together with a wavelength much wider than the one responsible for the relative vertical motions of the LHR and NCT.

\section{Conclusions}

Multibeam, seismic-reflection data, and rock samples from the southern NCT reveal a stratigraphic link between deformation of pre-Eocene strata on the basin flanks, their erosion and potential re-deposition as Eocene mass-transport deposits at the base of basin-margin slope. These syntectonic deposits, situated below the main basin onlap surfaces within the NCT, suggest that basin-margin slopes increased and were destabilised at the time of 
reverse-faulting and folding. New canyons formed that were locally diverted by growing folds, and basal strata within basin-floor fans deposited at canyon mouths were progressively deformed and uplifted. Subsequently, regional subsidence of $>1 \mathrm{~km}$ and volcanic quiescence submerged adjacent ridges and produced the present basin setting. However, this could be before the final phase of subsidence of the basin, which postdates Cretaceous rift-related subsidence. We indeed discuss the relative timing between subsidence in the NCT and deposition and deformation of Paleocene strata. Along with these data, this study bring new elements regarding deepwater sedimentation in a basin largely isolated from major terrigenous sources, at the exception of New Zealand and New Caledonia. We highlight deposition of flat-lying axial turbidites and hemipelagites within the basin, onlapping onto complex slope bedforms. These bedforms, conforming either to deepwater sediment waves or creep deformation features, point to active flow or slope instabily processes on the basinmargin slope.

In terms of future work, further lithological, biostratigraphical, paleoenvironmental calibrations of the seismic units described in this paper will ultimately help decipher the precise timing and depositional records of the geological events involved in the genesis of the New Caledonia Trough and its subsequent evolution.

\section{Acknowledgements}

We thank the crew of R/V Tangaroa and all students and NIWA technicians that were on Expeditions TAN1312 and TAN1409. This work was funded by the governments of New Zealand and New Caledonia and the French research program ZoNéCo of ADECAL Technopole. All data are available from GNS Science, New Zealand Petroleum and Minerals and the Geological Survey of New Caledonia. We also thank associate editor Tiago Alves, and reviews from Julien Bourget and an anonymous reviews for their relevant comments that greatly improved the manuscript. 


\section{References}

Alves, T. M. 2015. Submarine slide blocks and associated soft-sediment deformation in deep-water basins: A review. Marine and Petroleum Geology 67, pp. 262-285.

Anderskouv, K, Surlyk, F, Huuse, M, Lykke-Andersen, H, Bjerager, MGE \& Tang, CD 2010, Sediment waves with a biogenic twist in Pleistocene cool water carbonates, Great Australian Bight. Marine Geology, vol 278, pp. 122-139.

\section{Australian Geological Survey Organisation (1992), AGSO Marine Survey 114, Seismic log. Unpublished}

Bache, F., Sutherland, R., Stagpoole, V., Herzer, R.H., Collot, J. \& Rouillard, P. (2012) Stratigraphy of the Southern Norfolk Ridge and the Reinga Basin: a record of initiation of Tonga-Kermadec-Northland subduction in the Southwest Pacific. Earth Planetary Science Letters, 321-323, 41-53.

Bache, F., Mortimer, N., Sutherland, R., Collot, J., Rouillard, P., Stagpoole, V. \& Nicol, A. (2014a) Seismic stratigraphic record of transition from Mesozoic subduction to continental breakup in the Zealandia sector of Eastern Gondwana. Gondwana Research, 26, 1060-1078.

Bache, F., Sutherland, R. \& King, P.R. (2014b) Use of ancient wave-ravinement surfaces to determine palaeogeography and vertical crustal movements around New Zealand. New Zealand Journal of Geology and Geophysics, 57, 459-467.

Bache, F.; Sutherland, R.; Mortimer, N.; Browne, G.; Lawrence, M.J.F.; Black, J.; Flowers, M.; Rouillard, P.; Pallentin, A.; Woelz, S.; Wilcox, S.; Hines, B.; Jury, S.; Roop, H. (2014c). Tangaroa TAN1312 Voyage Report: Dredging Reinga and Aotea basins to constrain seismic Stratigraphy and Petroleum systems (DRASP), NW New Zealand, GNS Science Report 2014/05. 136p.

Baur, J.R., P.R. King, T. Stern, and B. Leitner, 2010, Depositional systems, seismic attributes, and tectonic subsidence history of offshore Taranaki Basin. New Zealand Petroleum Conference, Auckland NZL, New Zealand, p. 18

Baur, J., Sutherland, R. \& Stern, T. (2014) Anomalous passive subsidence of deep-water sedimentary basins: a prearc basin example, Southern New Caledonia Trough and Taranaki Basin, New Zealand. Basin Research, 26, 242-268.

Badalini, G. Kneller, B. \& Winker, C.D. (2000) Architecture and processes in the Late Pleistocene Brazos-Trinity turbidite System, Gulf of Mexico Continental Slope. In: Deep-water reservoirs of the world: $20^{\text {th }}$ Annual, 20, pp. 16-34. Society of economic paleontologists and mineralogists.

Berndt, C., Cattaneo, A., Szuman, M., Trincardi, F. \& Masson, D. (2006). Sedimentary structures offshore Ortona, Adriatic Sea - Deformation or sediment waves? Marine Geology, 234 (1-4),261-270.

Browne, G.H., Lawrence, M.J.F., Mortimer, N., Ventura, G.T., Clowes, C., Morgans, H.E.G., Seward, D., Barker, P.B., Lyndsell, B.M., Beu, A.G., Hollis, C.J. (2014). Analysis of rock samples collected during the TAN1312 dredging survey (DRASP) of Reinga and Aotea basins, NW New Zealand. GNS Science Consultancy Report 2014/267. 124 p.

Browne, G. H., Lawrence, M. J. F., Mortimer, N., Clowes, C. D., Morgans, H. E. G., Hollis, C. J.,Beu, A. G., Black, J. A., Sutherland, R., Bache, F. (2016). Stratigraphy of Reinga and Aotea basins, NW New Zealand: constraints from dredge samples on regional correlations and reservoir character. New Zealand Journal of Geology and Geophysics, 59(3), 396-415.

Burns, R. \& Andrews, J. (1973) Regional aspects of deep sea drilling in the Southwest Pacific. Initial Reports of the Deep Sea Drilling Project, 21, 897-906.

Burns, R. E., Andrews, J. E., van der Lingen, G. J., Churkin, M., Galehouse, J. S., Packham, G. H., Davies, T. A., Kennett, J. P., Dumitrica, P., Edwards, A. R., Von Herzen, R. P., Burns, D., and Webb, P. N., 1973, Site 206: Initial Reports of the Deep Sea Drilling Project, v. 21, p. 103-125. 
Cartigny, M. J. B., Postma, G., van den Berg, J. H., \& Mastbergen, D. R. (2011). A comparative study of sediment waves and cyclic steps based on geometries, internal structures and numerical modeling. Marine Geology, 280(1-4), 40-56.

Cartigny, M.J.B., Ventra, D., Postma, G., Can Den Berg, J.H. (2014) Morphodynamics and sedimentary structures of bedforms under supercritical-flow conditions: new insights from flume experiments. Sedimentology 61 (3), 712-748.

Cattaneo, A., A. Corregiari, T. Marsset, Y. Thomas, B. Marsset, \& F. Trincardi (2004), Seafloor undulation pattern on the Adriatic shelf and comparison to deep-water sediment waves, Mar. Geol.,213, 121-148.

Catuneanu, O., 2006. Principles of Sequence Stratigraphy, Developments in Sedimentology. Elsevier, Amsterdam, The Netherlands, 58.

Cluzel, D., Aitchison, J. C., \& Picard, C. (2001). Tectonic accretion and underplating of mafic terranes in the Late Eocene intraoceanic fore-arc of New Caledonia (Southwest Pacific): geodynamic implications. Tectonophysics, 340(1), 23-59.

Cluzel, D., Maurizot, P., Collot, J., \& Sevin, B. (2012). An outline of the geology of New Caledonia; from Permian-Mesozoic Southeast Gondwanaland active margin to Cenozoic obduction and supergene evolution. Episodes-Newsmagazine of the International Union of Geological Sciences, 35, 72.

Collot, J., Geli, L., Lafoy, Y., Vially, R., Cluzel, D., Klingelhoefer, F., Nouze, H., 2008. Tectonic history of northern New Caledonia Basin from deep offshore seismic reflection: relation to late Eocene obduction in New Caledonia, Southwest Pacific. Tectonics 27.

Collot, J., Herzer, R.H., Lafoy, Y. \& Geli, L. 2009. Mesozoic history of the Fairway - Aotea Basin: implications regarding the early stages of Gondwana fragmentation. Geochemistry, Geophysics, Geosystems 10.

Collot, J., Sutherland, R., Roest, W.R., Patriat, M., Etienne, S., Juan, C., Marcaillou, B., Schnurle, P., Barker, D., Stratford, W., Williams, S., Wolf, S., Bordenave, A., Roussel, C., 2016, TECTA voyage report, RV L'Atalante, Volume 1 - Text, Rapport SGNC-2016(01), 85 pp, doi : 10.17600/15001300

Ercilla G., Alonso B., Wynn R.B., Baraza J. 2002, Turbidity current sediment waves on irregular slopes: observations from the Orinoco sediment-wave field: Marine Geology, v. 192, p. 171-187.

Exon, N., Quilty, P., Lafoy, Y., Crawford, A.J. \& Auzende, J.-M. (2004) Miocene volcanic seamounts on Northern Lord Howe rise: lithology, age and origin. Australian Journal of Earth Science, 51, pp. 291-300.

Fildani, A., Normark, W.R., Kostic, S., Parker, G. (2006) Channel formation by flow stripping: largescale scour features along the Monterey East Channel and their relation to sediment waves. Sedimentology, 53, 1265-1287.

Gaina, C., Mueller, D.R., Royer, J.-Y., Stock, J., Hardebeck, J.L. \& Symonds, P. (1998) The tectonic history of the Tasman Sea: a puzzle with 13 pieces. Journal of Geophysical Research: Solid Earth, $103,12413-412433$.

Hackney, R., Sutherland, R. \& Collot, J. (2012). Rifting and subduction initiation history of the New Caledonia Trough, southwest Pacific, constrained by process-oriented gravity models. Geophysical Journal International, 189(3), 1293-1305.

He, Y., Zhong, G., Wang, L., and Kuang, Z., 2014, Characteristics and occurrence of submarine canyon-associated landslides in the middle of the northern continental slope, South China Sea: Marine and Petroleum Geology, v. 57, no. Supplement C, p. 546-560.

Herzer, R. H., Barker, D. H. N., Roest, W. R., \& Mortimer, N. (2011). Oligocene-Miocene spreading history of the northern South Fiji Basin and implications for the evolution of the New Zealand plate boundary. Geochemistry, Geophysics, Geosystems, 12(2).

Howe, J.A., Livermore, R.A., Maldonado, A., 1998. Mudwave activity and current-controlled sedimentation in Powell Basin, Northern Weddell Sea, Antarctica. Marine Geology. 149, 229-241. 
Kennett, J.P., Burns, R.E., Andrews, J.E., Churkin, M. Jr, Davies, T.A., Dumitrica, P., Edwards, A.R., Galehouse, J.S., Packham, G.H. \& Van Der Lingen, G.J. (1972) Australian-antarctic continental drift, palaeocirculation changes and oligocene deep-sea erosion. Nature Physical Science, 239, 51-55.

Kennett, J.P., Houtz, R.E., Andrews, P.B., Edwards, A.R., Gostin, V.A., Hajos, M., Hampton, M.A., Jenkins, D.G., Margolis, S.V., Ovenshine, A.T. \& Perch-Nielsen, K. (1975) Cenozoic oceanography in the southwest Pacific Ocean, antarctic glaciation, and the development of the circum-antarctic current. In: Initial Reports of the Deep Sea Drilling Project - Leg 29 (Ed. by J.P. Kennett, R.E. Houtz, P.B. Andrews, A.R. Edwards, V.A. Gostin, M. Hajos, M.A. Hampton, D.G. Jenkins, S.V. Margolis, A.T. Ovenshine \& K. Perch-Nielsen), pp. 121-223. U.S. Government Printing Office, Washington, USA.

King, P. R., and G. P. Thrasher (1992), Post-Eocene development of the Taranaki Basin, New Zealand; convergent overprint of a passive margin, in Geology and geophysics of continental margins AAPG Memoir, edited by J. S.Watkins, Z. Feng, and K. J. McMillen, vol. 53, pp. 93-118, Am. Assoc. Petrol. Geol., Tulsa.

Lafoy, Y., Brodien, I., Vially, R., \& Exon, N. (2005). Structure of the basin and ridge system west of New Caledonia (Southwest Pacific): a synthesis. Marine Geophysical Researches, 26(1), pp. 37-50.

Lee, H.J., Syvitski, J.P.M., Parker, G., Orange, D., Locat, J., Hutton, E.W.H., Imran, J., 2002. Distinguishing sediment waves from slope failure deposits: field examples, including the"Humboldt Slide" and modeling results. Marine Geology, 192, 79-104.

Lee, S.H., and Chough, S.K., 2001, High-resolution (2-7 kHz) acoustic and geometric characters of submarine creep deposits in the South Korea Plateau, East Sea: Sedimentology, v. 48, p. 629-644

Li W., Alves T.M., Wu S., Rebesco M., Zhao F., Mi L., Ma B. (2016) A giant, submarine creep zone as a precursor of large-scale slope instability offshore the Dongsha Islands (South China Sea), Earth and Planetary Science Letters, 451 , 272-284.

Lister, G.S., Etheridge, M.A. \& Symonds, P.A. (1991) Detachment models for the formation of passive continental margins. Tectonics, 10, 1038-1064.

Luyendyk, B. (1995) Hypothesis for Cretaceous rifting of East Gondwana caused by subducted slab capture: Geology, v. 23, p. 373-376.

Marshall, J. F., Feary, D., \& Zhu, H. (1994). Geological framework of the southern Lord Howe Rise / West Norfolk Ridge region. Australian Geological Survey Organisation record, 65, 43.

Matthews, K.J., Williams, S.E., Whittaker, J.M., Müller, R.D., Seton, M., and Clarke, G.L., 2015, Geologic and kinematic constraints on Late Cretaceous to mid Eocene plate boundaries in the southwest Pacific: Earth-Science Reviews, v. 140, p. 72-107.

Maurizot, P. (2012). Palaeocene age for the Adio Limestone, New Caledonia: stratigraphic and regional context. New Zealand Journal of Geology and Geophysics, 56(1), 16-26

Mitchum, R.M. (1977) Seismic stratigraphy and global changes of sea level; Part 11, Glossary of terms used in seismic stratigraphy. In: Seismic stratigraphy; applications to hydrocarbon exploration (Ed C.E. Payton), AAPG Memoir Volume 26, pp. 205-212.

Mortimer, N. (2008) Zealandia. In: Circum Pacific Tectonics, Geologic Evolution, and Ore Deposits (Ed. by Spencer J.E. \& Tithley S.R.) Arizona Geol. Soc., 22, 227-233. Tucson.

Mortimer, N., Hauff, F. \& Calvert, A.T. (2008) Continuation of the New England Orogen, Australia, beneath the Queensland Plateau and Lord Howe Rise. Australian Journal of Earth Sciences, 55, 195209.

Mortimer, N., Gans, P. B., Palin, J. M., Meffre, S., Herzer, R. H., \& Skinner, D. N. B. (2010). Location and migration of Miocene-Quaternary volcanic arcs in the SW Pacific region. Journal of Volcanology and Geothermal Research, 190(1-2), 1-10.

Mortimer, N., Campbell, H., Tulloch, A., Sutherland, R., Stagpoole, V., Adams, C., Rattenbury, M., King, P., Collot, J., Seton, M. (2017a) Zealandia: Earth's hidden continent, GSA Today, 27 (3), pp. 2735. 
Mortimer, N., Gans, P., Meffre, S., Martin, C. E., Seton, M., Williams, S. E., Turnbull, R. E., Quilty, P. G., Micklethwaite, S., Sutherland, R., Bache, F., Timm, C., Collot, J. , Maurizot, P., \& Rollet, N. (2017b). Regional volcanism of northern Zealandia: post-Gondwana breakup magmatism on an extended, submerged continent. Geological Society of London Special Publications, 463.

Nouzé, H., Cosquier, E., Collot, J., Foucher, J.-P., Klingelhoefer, F., Lafoy, Y. \& Géli, L. (2009) Geophysical characterization of bottom simulating reflectors in the Fairway Basin (Off New Caledonia, Southwest Pacific), based on high resolution seismic profiles and heat flow data. Marine Geology, 266, 80-90.

Parker, G., (1996) Some speculations on the relation between channel morphology and channel-scale flow structures. Coherent Flow Structures in Open Channels, vol. 423.

Postma, G., Fortuin, A.R., van Wamel, W.A., 1993. Basin-fill patterns controlled by tectonics and climate: the Neogene 'fore-arc' basins of eastern Crete as a case history. In: Frostick, L.E., Steel, R.J. (Eds.), Tectonic Controls and Signatures in Sedimentary Successions, International Association of Sedimentologists, Special Publications, 20, 335-362.

Postma, G., \& Cartigny, M. J. B. (2014). Supercritical and subcritical turbidity currents and their deposits - A synthesis. Geology, 42(11), 987-990.

Rouillard, P., Collot, J., Sutherland, R., Bache, F., Patriat, M., Etienne, S. and Maurizot, P. (2017), Seismic stratigraphy and paleogeographic evolution of Fairway Basin, Northern Zealandia, Southwest Pacific: from Cretaceous Gondwana breakup to Cenozoic Tonga-Kermadec subduction. Basin Research, 29: 189-212.

D.J. Shillington, L. Seeber, C.C. Sorlien, M.S. Steckler, H. Kurt, D. Dondurur, G. Çifçi, C. İmren, M.-H. Cormier, C.M.G. McHugh, S. Gürçay, D. Poyraz, S. Okay, O. Atgın, J.B. Diebold; Evidence for widespread creep on the flanks of the Sea of Marmara transform basin from marine geophysical data. Geology ; 40 (5): 439-442.

Smith, W. H. F. and D. Sandwell, 1997.Global seafloor topography from satellite altimetry and ship depth soundings, Science, 277, p.1956-1962.

Smith, R. \& Joseph, P. (2004) Onlap stratal architectures in the Grès d'Annot: geometric models and controlling factors. In: Deep water sedimentation in the Alpine basin of SE France. New perspectives on the Grès d'Annot and related systems (Eds P. Joseph and S.A. Lomas, Geological Society, London, Special Publications, 221:389-399.

Smith, R. (2004) Silled sub-basins to connected tortuous corridors: sediment distribution systems on topographically complex sub-aqueous slopes. In: Confined Turbidite Systems (Eds S.A. Lomas and P. Joseph), Geological Society, London, Special Publications, 222, pp. 23-43.

Sutherland, R. (1999) Basement geology and tectonic development of the greater New Zealand region: an interpretation from regional magnetic data. Tectonophysics, 308, 341-362.

Sutherland, R., Collot, J., Lafoy, Y., Logan, G.A., Hackney, R., Stagpoole, V., Uruski, C., Hashimoto, T., Higgins, K., Herzer, R.H., Wood, R., Mortimer, N. \& Rollet, N. (2010) Lithosphere delamination with foundering of lower crust and mantle caused permanent subsidence of New Caledonia Trough and transient uplift of Lord Howe Rise during Eocene and Oligocene initiation of Tonga-Kermadec subduction, Western Pacific. Tectonics, 29.

Sutherland, R., Viskovic, P., Bache, F., Stagpoole, V., Collot, J., Rouillard, P., Hashimoto, R., Hackney, R., Higgins, K., Rollet, N., Roest, W. \& Patriat, M. (2012) Compilation of seismic reflection data from the Tasman frontier region, Southwest Pacific. GNS Sci. Rep., 2012/01, 57p.

Sutherland, R., Collot, J., Henrys, S., Barker, D., Mueller, C., Juan, C., Woelz, S., Gerring, P., Quinn, W., Boyes, A., Collins, K., O'Brien, G., Potaka, G., White, J., Fernandez, J. Skorstengaard, P., CappeKerbart, C. 2014. TAN1409 voyage Report: Tasman Frontier Geophysical Survey, RV Tangaroa, 19 July - 12 August 2014, GNS Science Report 2014/72. 65p.

Sutherland, R., Collot, J., Bache, F., Henrys, S., Barker, D., Browne, G.H., Lawrence, M.J.F., Morgans, H., Hollis, C.J., Clowes, C., Mortimer, Nick, Rouillard, P., Gurnis, M., Etienne, S., Stratford, 
W. (in press). Widespread compression associated with Eocene Tonga-Kermadec subduction initiation. Geology. doi: 10.1130/G38617.1

750 Symons, W. O., Sumner, E. J., Talling, P. J., Cartigny, M. J. B., \& Clare, M. A. (2016). Large-scale

751 sediment waves and scours on the modern seafloor and their implications for the prevalence of 752 supercritical flows. Marine Geology, 371, 130-148.

753 Vail, P.R., Mitchum, R.M., Thompson, S. (1977) Seismic stratigraphy and global changes of sea level; 754 Part 4, Global cycles of relative changes of sea level. In: Seismic Stratigraphy: Applications to 755 Hydrocarbon Exploration (Ed C.E. Payton), AAPG Memoir Volume 26, pp. 83-97.

756 Van De Beuque, S., Auzende, J.-M., Lafoy, Y. \& Missegue, F. (1998) Tectonique et volcanisme 757 tertiaire sur la ride de Lord Howe (Sud-Ouest Pacifique). Comptes Rendus de l'Académie des 758 Sciences, Séries IIA - Earth and Planetary Science, 326, pp. 663-669.

759 Willcox, J., Symonds, P., Hinz, K., \& Bennett, D. (1980). Lord Howe Rise, Tasman Sea-preliminary 760 geophysical results and petroleum prospects. BMR J. Aust. Geol. Geophys, 5(3), 225-236.

761 Wynn, R.B., Stow, D.A.V., 2002. Classification and characterisation of deep-water sediment waves. 762 Marine Geology 192 (1-3), 7-22. 


\section{Figures and Figure Captions}
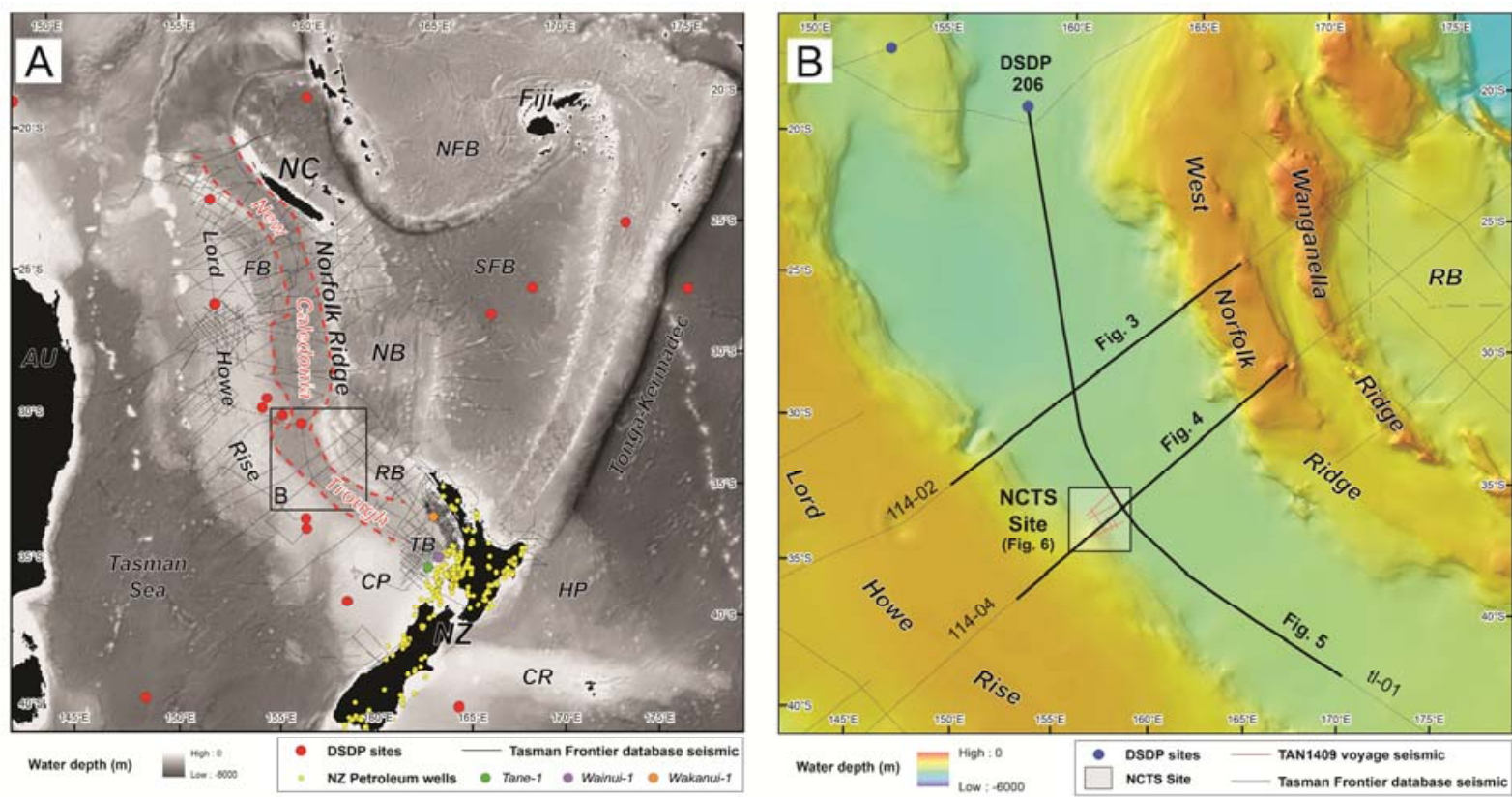

Figure 1: A. Regional bathymetric map of the South West Pacific between New Zealand and New Caledonia with position of the New Caledonia Through (NCT, dotted red line) and main geological features (AU: Australia, NZ: New Zealand, NC: New Caledonia, HP: Hikurangi Plateau, CR: Chatham Rise, NFB: North Fiji Basin, SFB: South Fiji Basin, NB: Norfolk Basin, RB: Reinga Basin, TB: Taranaki Basin, CP: Challenger Plateau, FB: Fairway Basin). Position of seismic data of the Tasman Frontier Database (Sutherland et al., 2012), Deep Sea Drilling Project (DSDP) sites and New Zealand's petroleum wells are shown as solid black lines, red dots and yellow dots, respectively. Relevant wells for the stratigraphy of deepwater Taranaki and NCT are highlighted. B. Bathymetric map of the southern part of the NCT with location of the study area (NCTS Site) and position of the regional seismic lines shown in this paper (strike lines 114-02 and 114-04, figures 3 and 4 respectively and dip line TL-01, figure 5). Bathymetric data are from Global Predicted Bathymetry V18.1 (Smith \& Sandwell, 1997). 


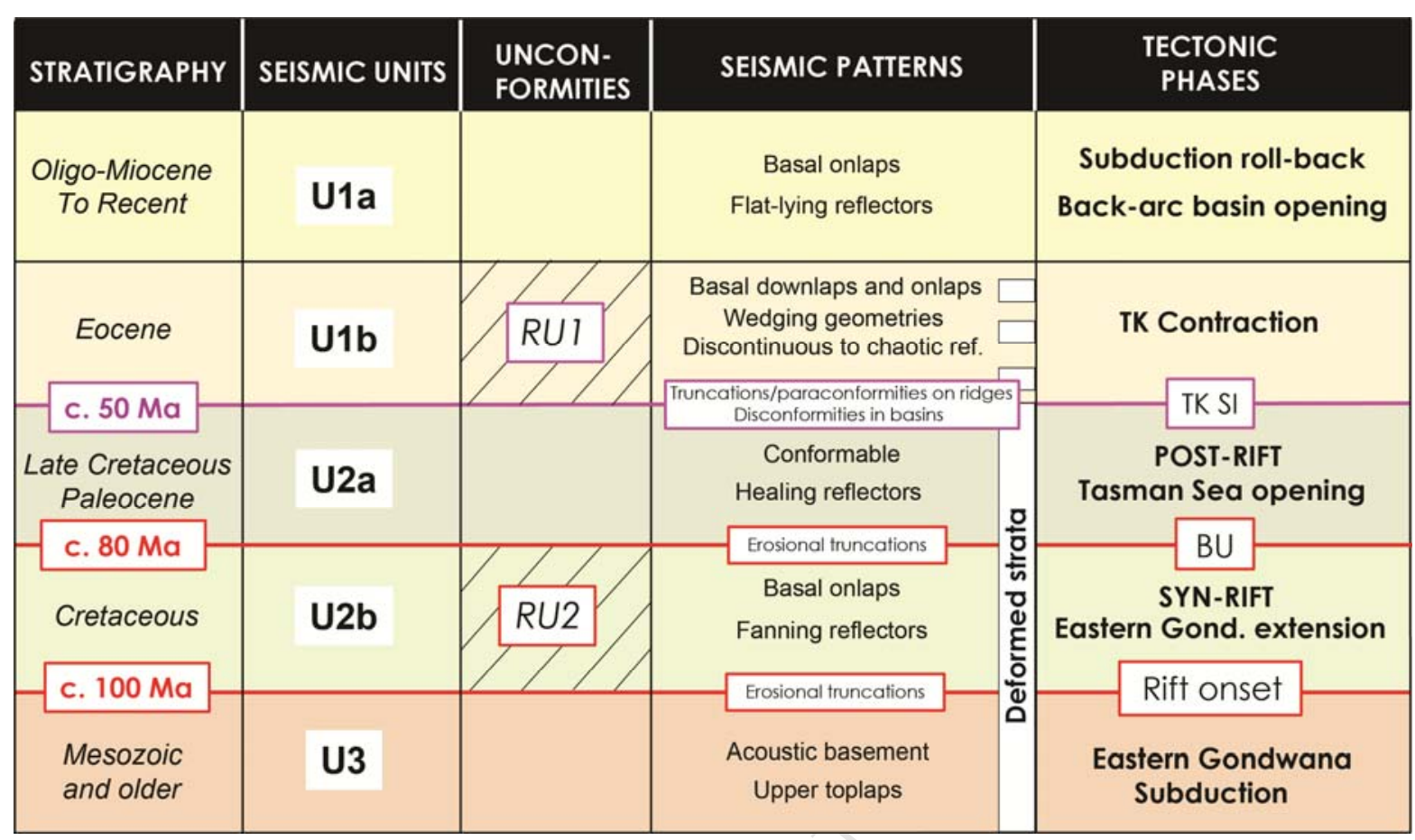

Figure 2: Regional scale first order seismic sequence scheme used in this study (adapted from Bache et al., 2014a and Rouillard et al., 2017) with main unconformities, inferred stratigraphic ages, distinctive seismic stratal patterns and associated key tectonic phases. This stratigraphic framework is thought to be overall consistent across northern Zealandia sedimentary basins (eg. New Caledonia Trough, Reinga Basin) and comprises three megasequences (U3, U2 and U1 from bottom-up) related to regional events, from Eastern Gondwana active margin (U3), Late Cretaceous syn-rift (U2b), LateCretaceous-Paleocene post-rift (U2a) to Eocene compression (U1b) likely to be linked with subduction inception and subsequent Oligocene to Neogene roll-back (U1a). The two regional unconformities, $\mathrm{RU} 2$ and RU1, correspond to a rift onset / continental break-up (BU) composite unconformity and to the Eocene-Oligocene unconformity, respectively, the latter being interpreted as representing TongaKermadec subduction inception (TK SI). 

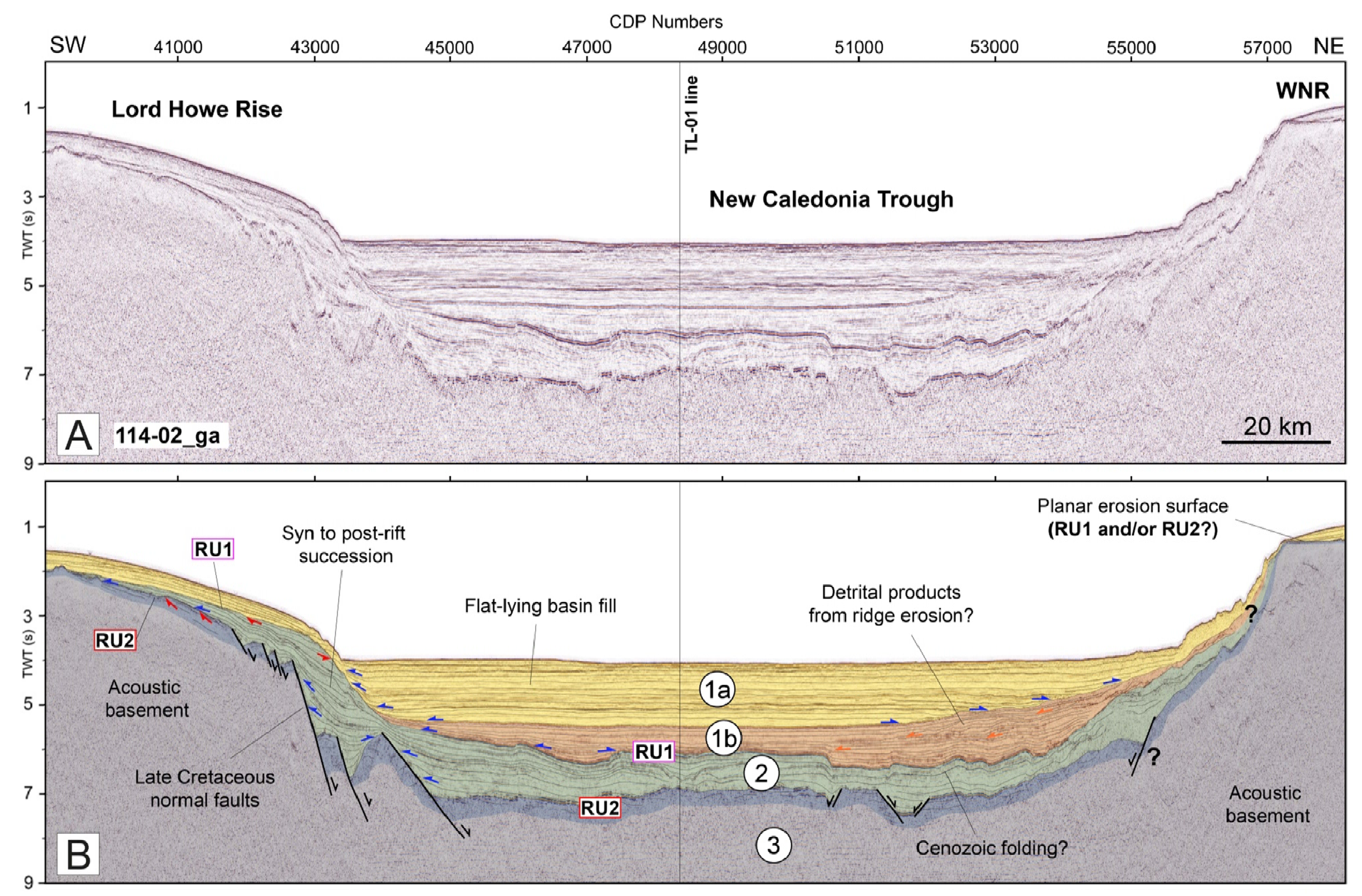


\section{ACCEPTED MANUSCRIPT}

Figure 3: A. Regional seismic line 114-02 across the southern NCT, between the Lord Howe Rise and West Norfolk Ridge (WNR). Line location is indicated on figure 1B. B. Schematic interpretation of line 114-02 with regional scale seismic stratigraphic units (adapted from Bache et al., 2014a), from acoustic basement to faint chaotic/deformed reflections (Unit 3), deformed Late Cretaceous rift-related strata (Unit 2), onlapping to downlapping anisopaceous strata (Unit 1b) and undeformed basin infill with clear lateral onlap configuration of overall flat-lying reflections (Unit 1a). Note the Late Cretaceous normal faulting of Unit 2 on the western side of the basin but also the subtle folding of the unit along the axis of the trough. Blue, orange and red arrows indicate onlap, downlap and toplap configurations, respectively. 


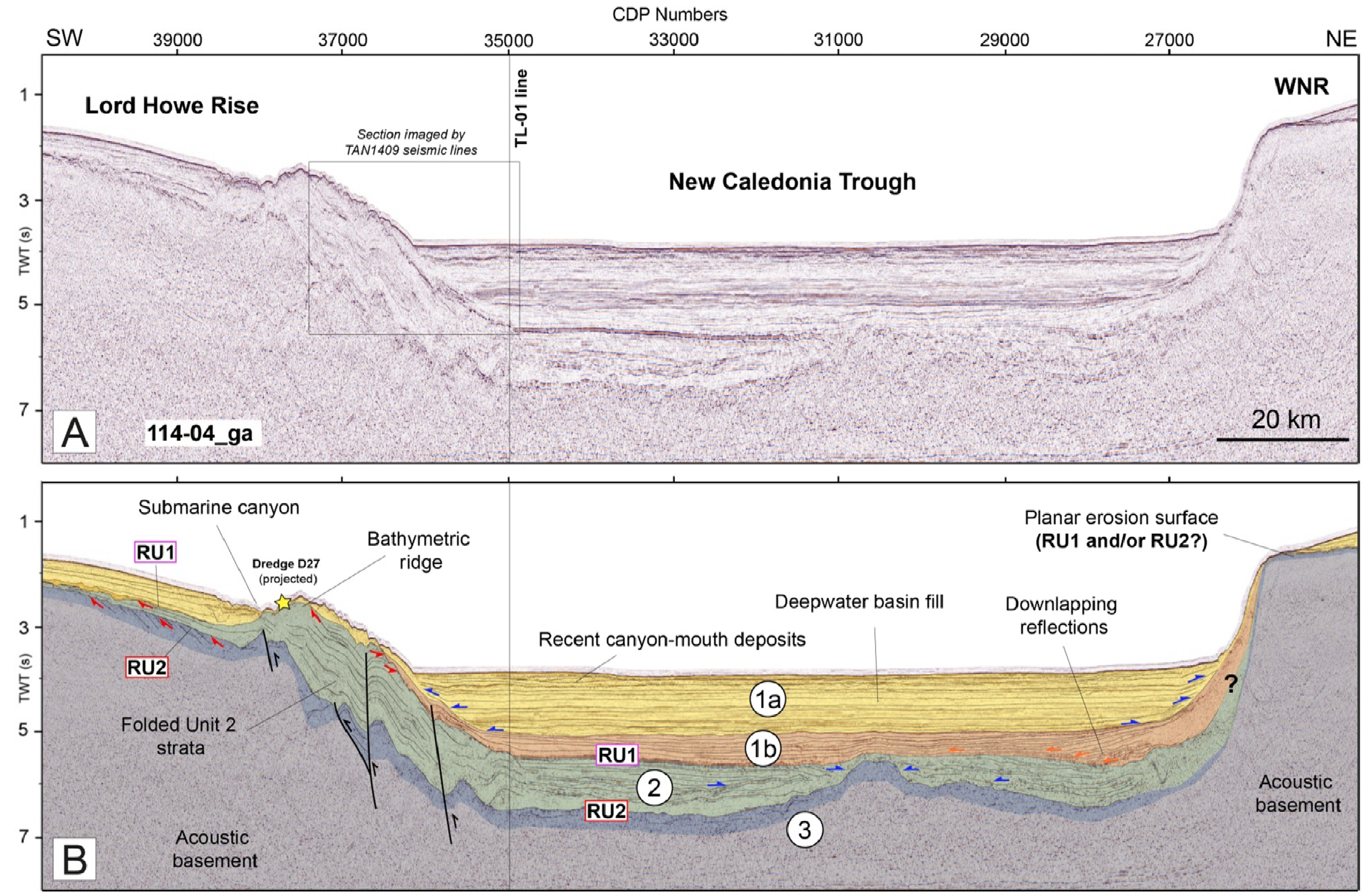




\section{ACCEPTED MANUSCRIPT}

Figure 4: A. Regional seismic line 114-04 across the southern NCT, roughly parallel and $90 \mathrm{~km}$ south of line 114-02 (Fig. 3). Line location is indicated on figure 1B. The section imaged by the seismic data of the TAN1409 Expedition is indicated by a black rectangle, on the western slope of the basin. B. Schematic interpretation of seismic line 114-04 with main seismic stratigraphic units (adapted from Collot et al., 2009; Bache et al., 2014a; Sutherland et al., 2010; 2017), from acoustic basement to faint deformed reflections (Unit 3), deformed rift-related strata (Unit 2), onlapping to downlapping strata (Unit 1b) and flat-lying deepwater basin infill with lateral onlaps (Unit 1a). On the western side of the basin, Unit 2 is folded potentially due to the reactivation of Late Cretaceous normal faults. This deformed structure is the focus of the TAN1409 seismic survey. Blue, orange and red arrows indicate onlap, downlap and toplap configurations, respectively. 


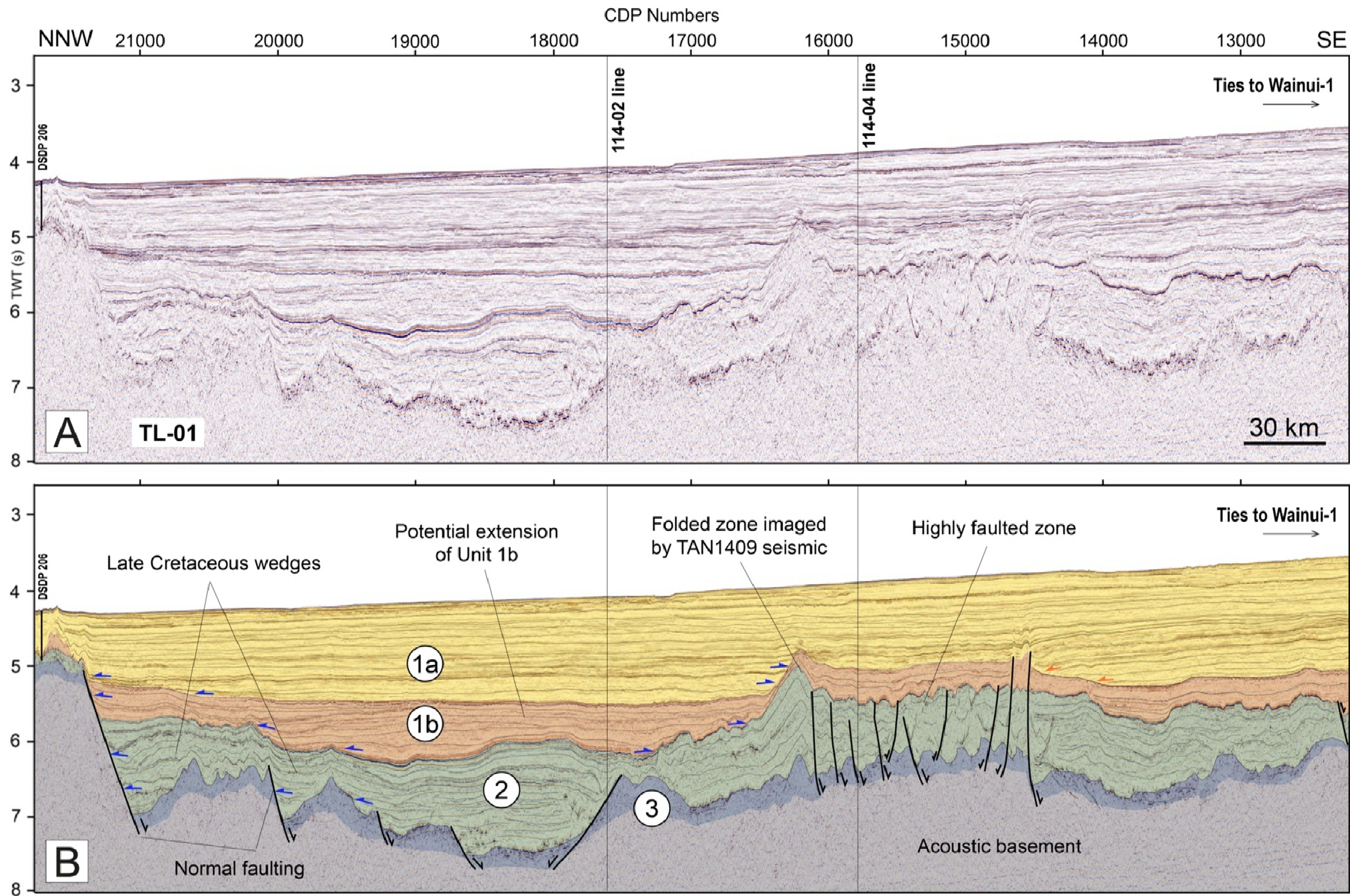




\section{ACCEPTED MANUSCRIPT}

Figure 5: A. Regional seismic line TL-01 along the southern NCT, crossing both lines 114 (see Fig. 1B for location). B. Schematic interpretation of line TL-01 showing regional seismic units, U3 to U1 (modified from Collot et al., 2009). The area investigated by the TAN1409 survey is part of a larger scale deformed zone affecting Unit 2 strata over approximately $110 \mathrm{~km}$ in length. Blue, orange and red arrows indicate onlap, downlap and toplap configurations, respectively. 


\section{ACCEPTED MANUSCRIPT}

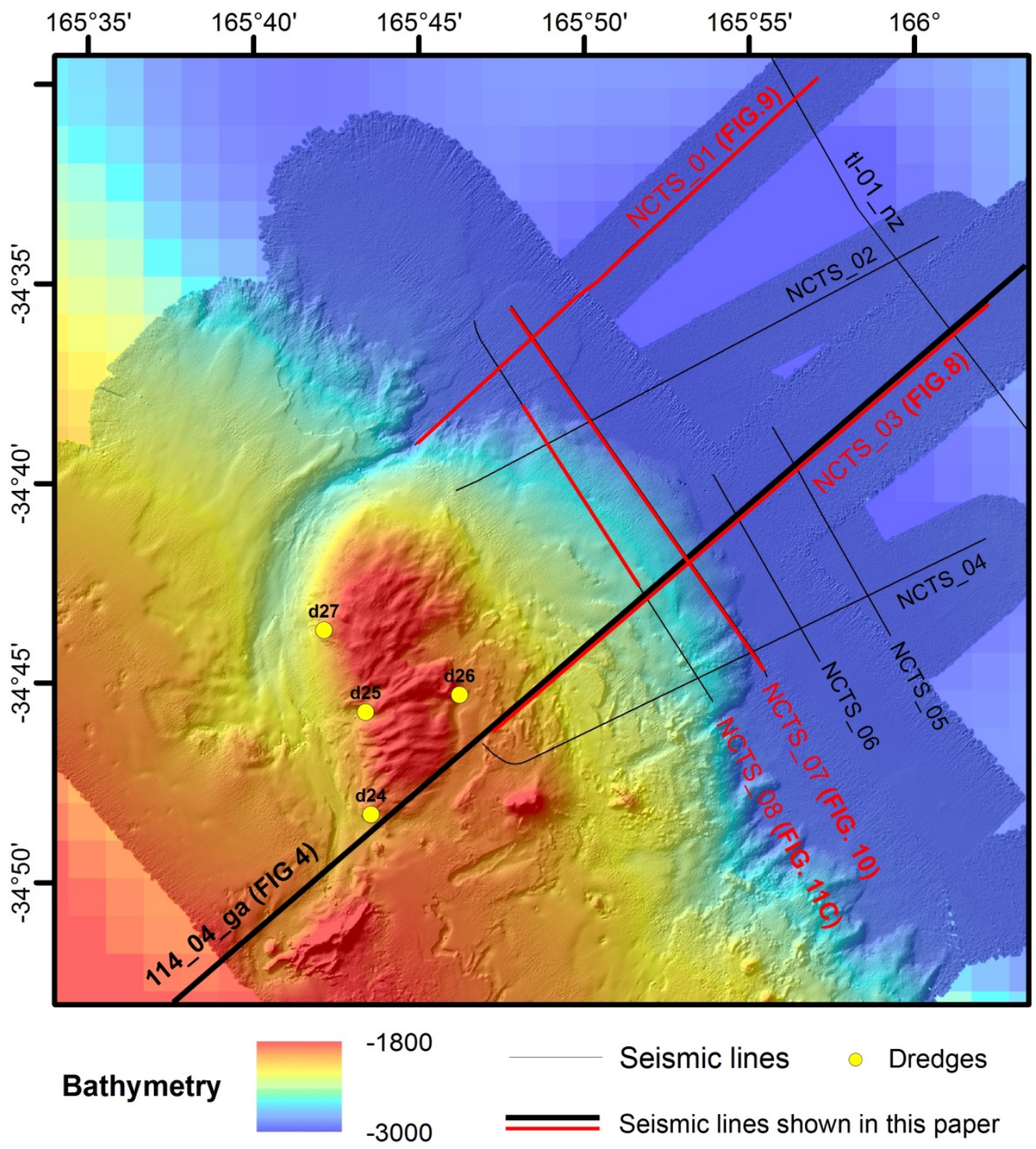

Figure 6: Swath bathymetry map of the study area, informally called New Caledonia Trough South site (NCTS) on the western margin of the NCT, ie. on the Lord Howe Rise eastern slope (multibeam data compiled from the TAN1409 and TAN1312 Expedition). Position of all data used in this study is shown. This includes multichannel seismic lines from the TAN1409 Expedition and Tasman Frontier Database (Sutherland et al., 2014, 2012 respectively) and rock sample dredges from the TAN1312 Expedition (Bache et al., 2014c; Browne et al., 2014; Browne et al., 2016; Mortimer et al., 2017). 

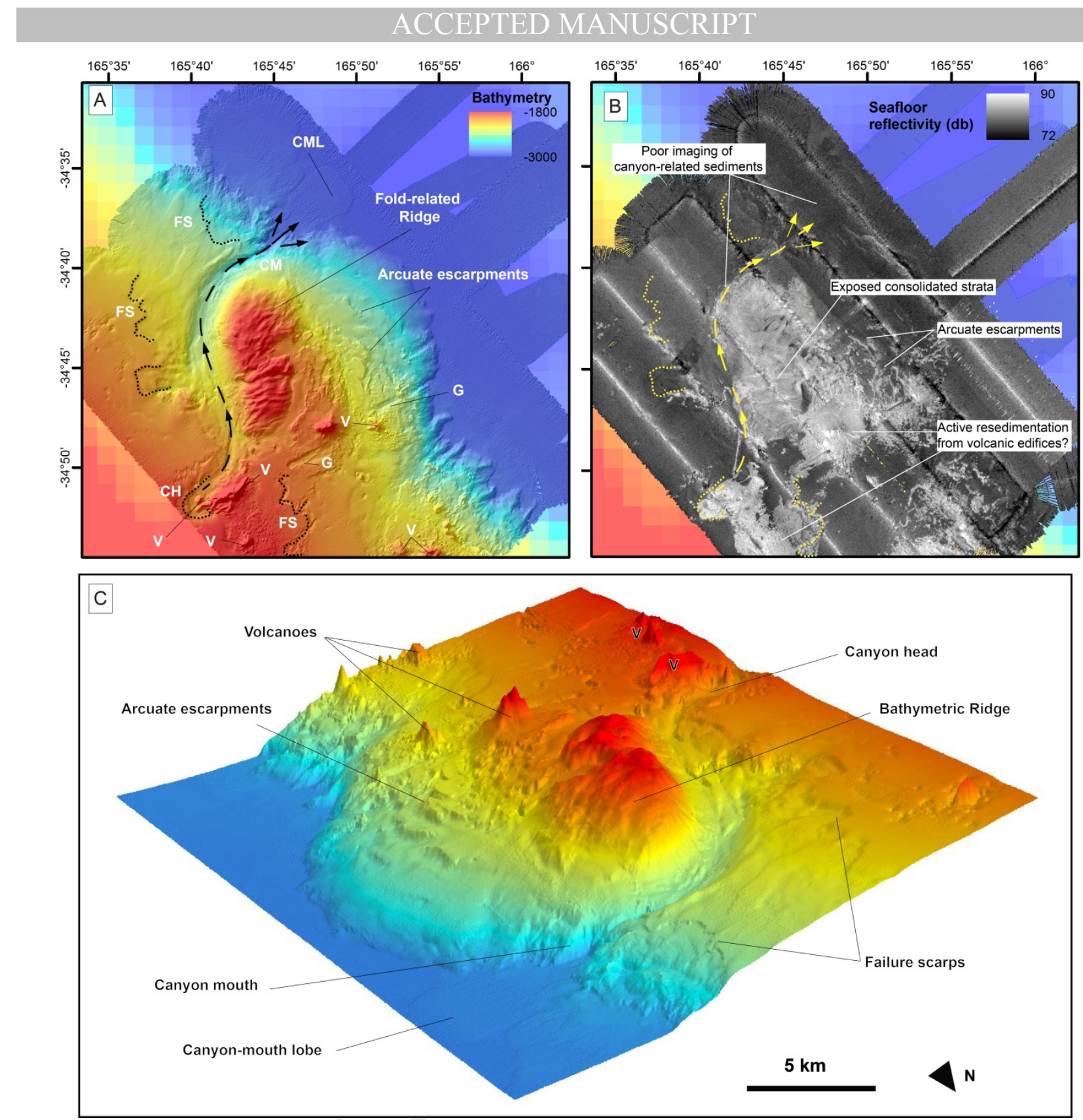

Figure 7: A. Swath bathymetry map of the NCTS site with interpretation of main seafloor morphological features. The NE-dipping slope is affected by a $30 \mathrm{~km}$-long and up to $250 \mathrm{~m}$-deep submarine canyon imaged from its headscarp ( $\mathrm{CH}$ : Canyon Head) to its mouth, feeding a relatively restricted, low-relief $\sim 10$ m-thick sediment lobe (CML: Canyon mouth lobe). The canyon is diverted by a small bathymetric ridge formed by the partial exposure of Unit 2 folded strata (see Fig. 4). Other gravity related features are visible, yet of smaller scale, such as failure scarps (FS) and linear gullies (G). Punctual, rounded bathymetric highs are thought to correspond to volcanic edifices (V). Arcuate ridges are clearly visible on the eastern side of the ridge toward the basin and could correspond either to turbidite sandwaves or creep related features (see details in the discussion). B. Backscatter 


\section{ACCEPTED MANUSCRIPT}

imagery map, revealing acoustic reflectivity of the seafloor. This map, primarily showing the degree of induration of seafloor sediments/rocks highlights high slope values as well as zones of potentially active slope resedimentation. Volcanoes and associated radial aprons of sediments are clearly imaged, as well as the ridge formed by the exposed strata of Unit 2. Although clearly identified on the swath bathymetry, the small-scale canyon-lobe system is not clearly associated with higher reflectivity values, suggesting relative canyon inactivity and/or poorly consolidated fine-grained sediments. C. SW-looking three-dimensional image of the NCTS bathymetry with main morphological features. 

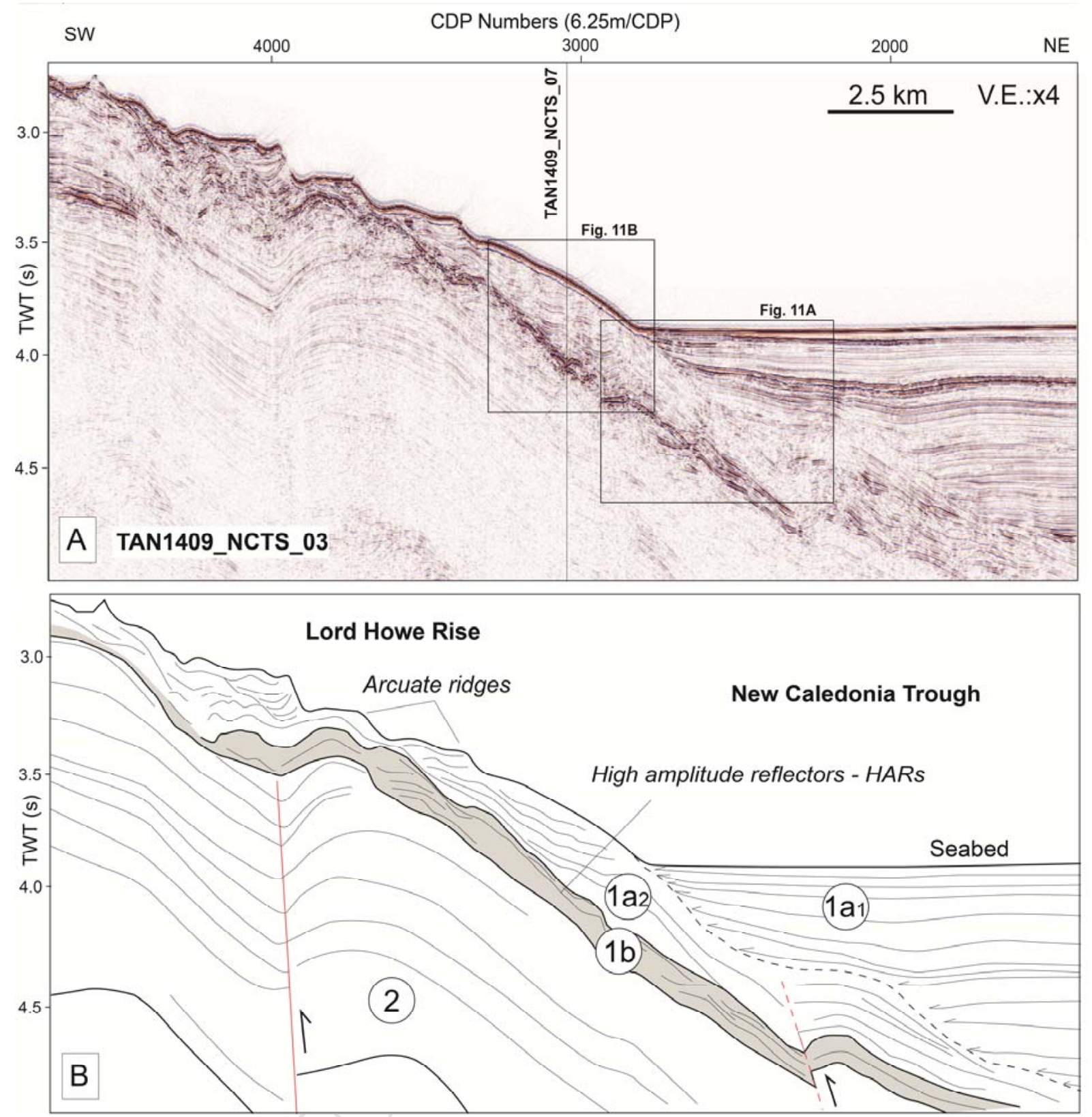

Figure 8: Multichannel seismic line NCTS-03 from the TAN1409 Expedition (A) and its summary line drawing interpretation (B). In comparison with line 114-04, this higher resolution line provides significant details on the seismic stratal relationships overlying the folded and inversely faulted structures of Unit 2. Folds are cut by an irregular erosional surface (RU1 unconformity?), evidenced by clear truncations of Unit 2 reflections. This unconformity forms the base of Unit $1 b$, which comprises high amplitude reflectors (HARs) displaying complex wavy to deformed geometries. Above this, Unit 1a shows two distinct seismic facies, from flat-lying onlapping reflections in the basin $\left(1 a_{1}\right)$ to upslope dipping reflections $\left(1 a_{2}\right)$. Location of seismic line is provided on Figure 6. 


\section{ACCEPTED MANUSCRIPT}
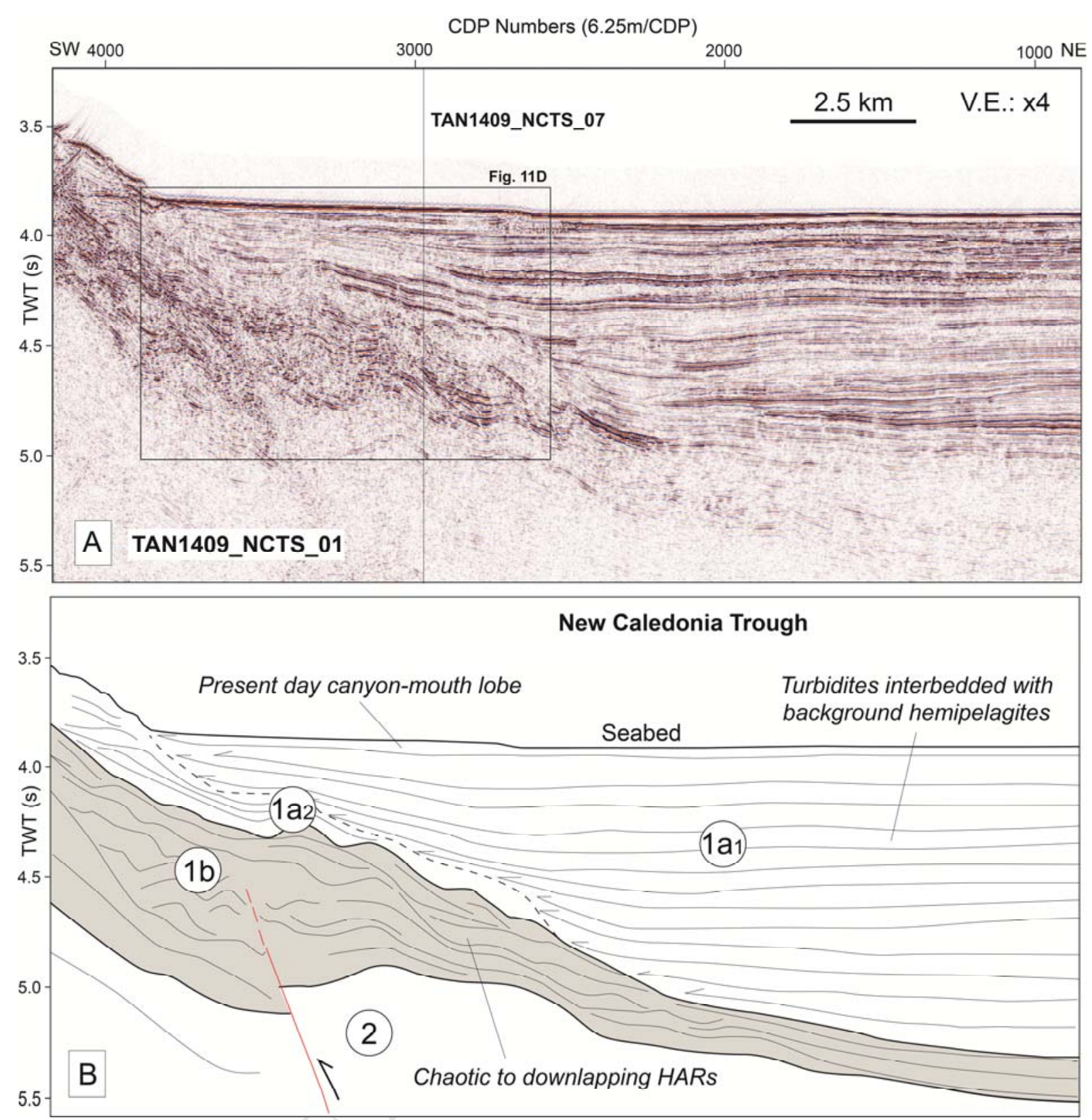

Figure 9: Multichannel seismic line NCTS-01 from the TAN1409 Expedition (A) and its summary line drawing interpretation (B). This line, located at the mouth of the submarine canyon imaged on the swath bathymetry, reveals a very thick Unit $1 \mathrm{~b}$ (up to $c$. $0.5 \mathrm{~s}$ twt) composed of high amplitude reflectors (HARs), with chaotic to locally downlapping geometries (see close-upin Fig. 11). Note the thin, poorly erosive present day canyon-mouth lobe on top of Unit $1 a_{1}$. Location of the seismic line is provided on Figure 6. 


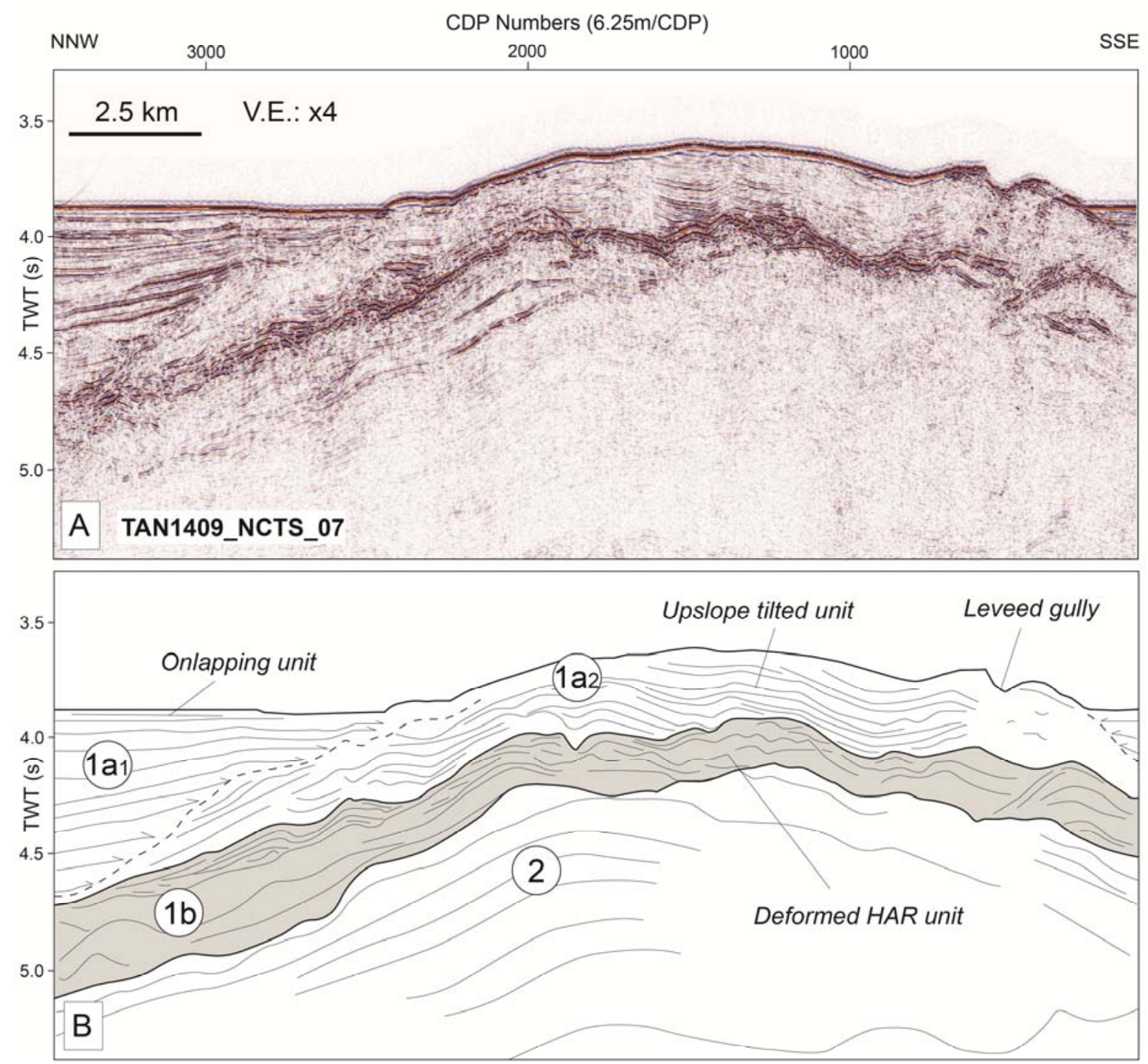

Figure 10: Multichannel seismic line NCTS-07 from the TAN1409 Expedition (A) and its summary line drawing interpretation (B). It reveals the across-strike geometry of the main seismic units which suggest anticlinal fold deformation and apparent thickening of Unit $1 b$ towards the NNW. Across strike geometry of Unit $1 \mathrm{a}_{2}$ are also clearly imaged. Note the small-scale leveed gully on the right hand side of the seismic line, likely to be fed by reworked sediment coming off the nearby volcanoes. 

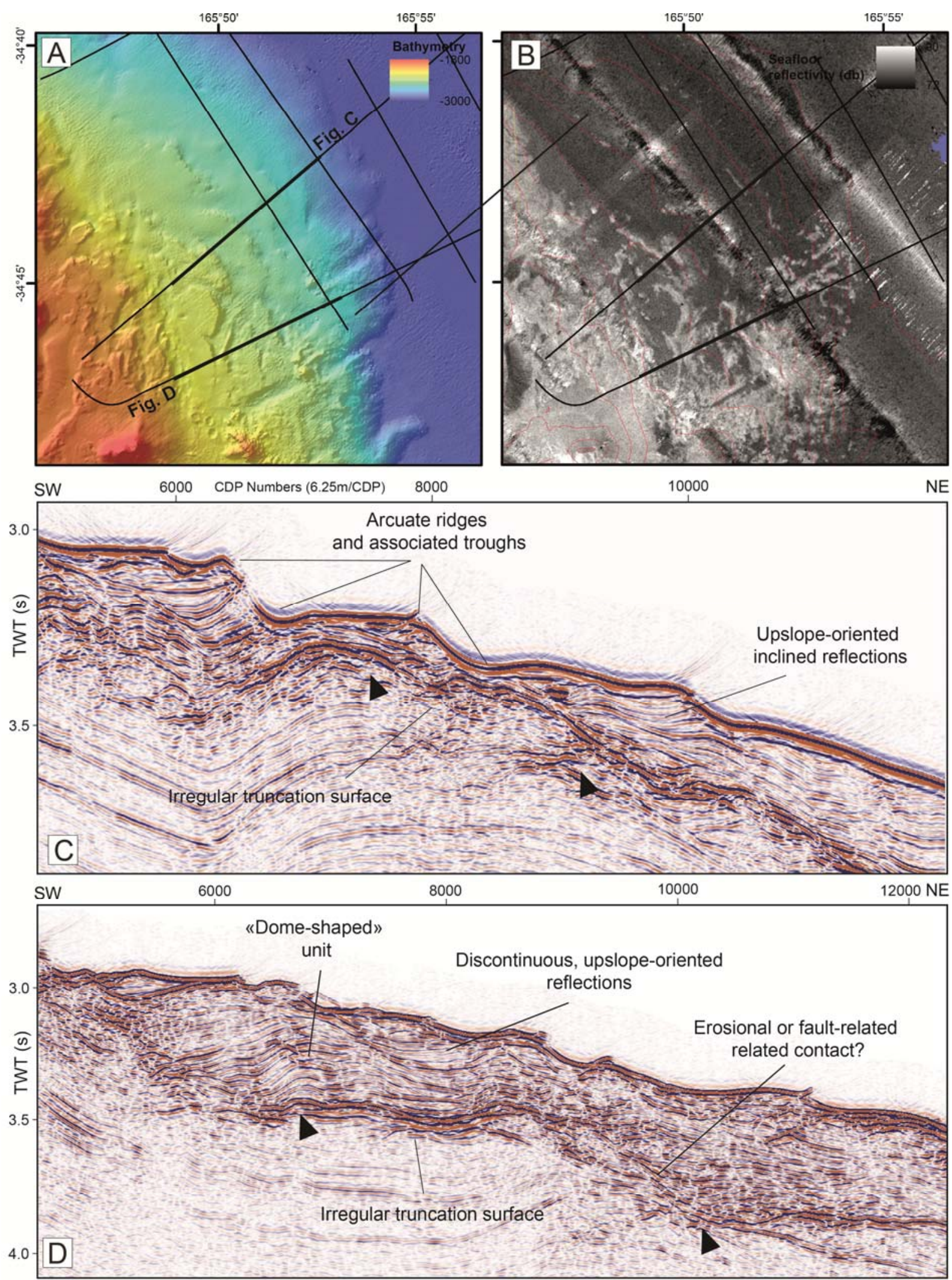

Figure 11: Detailed examples of seismic facies and stratal relationships within and between seismic units differentiated in this study. A. Details of abrupt onlap configuration of flat-lying reflections of Unit $1 a_{1}$ onto more complex geometry reflections of slope unit $1 a_{2}$. Note the high amplitude, wavy to 
mounded reflections of Unit $1 \mathrm{~b}$, developed over a truncation surface (indicated by black arrows). B. Clearly upslope tilted reflections of Unit $1 \mathrm{a}_{2}$, onlapping onto Unit $1 \mathrm{~b}$ high amplitude reflections. C. Seismic character of Unit $1 \mathrm{~b}$ comprising a low amplitude, chaotic to transparent facies. D. Chaotic and higher amplitude reflections of Unit $1 \mathrm{~b}$, below the basinal onlap of Unit $1 \mathrm{a}_{1}$, situated at the mouth of the submarine slope canyon imaged on swath bathymetry.
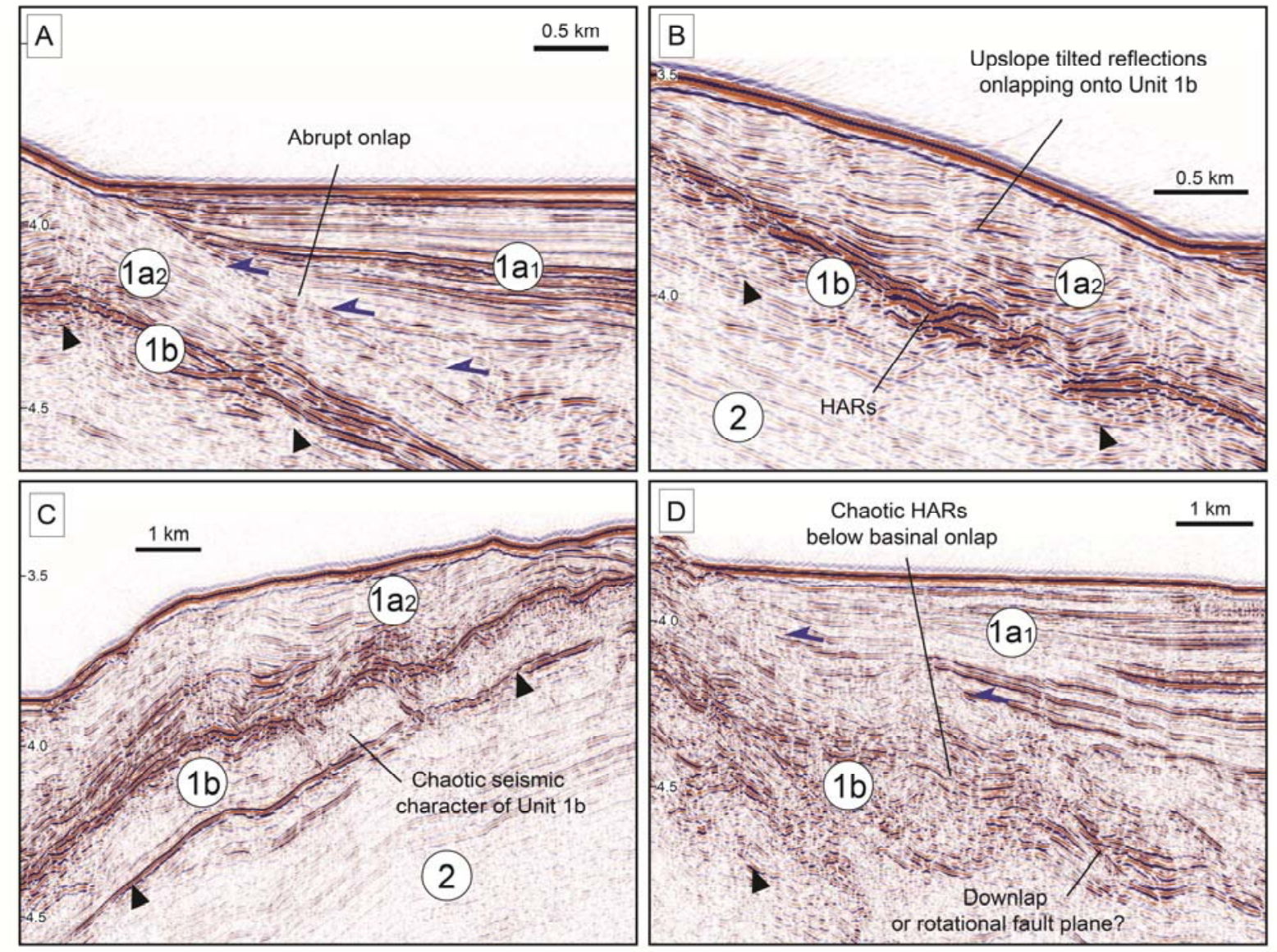

Figure 12: Close-up views on arcuate ridges (and associated troughs) on available swath bathymetry (A) and backscatter imagery (B). C. Seismic zoom on these undulating features. Internal reflections are parallel and upslope dipping, possibly reflecting upslope migration of turbidite bedforms or, alternatively slow internal deformation such as creep (location of line section is indicated on figure A). D. Seismic zoom on constructive(?) bedforms of Unit $1 \mathrm{a}_{2}$ as dome-shaped aggrading geometries overlain by discontinuous upslope dipping reflections. Note the limited thickness of Unit $1 \mathrm{~b}$, almost pinching-out onto the truncation surface on top of Unit 2 (location of line section is indicated on figure A.). 


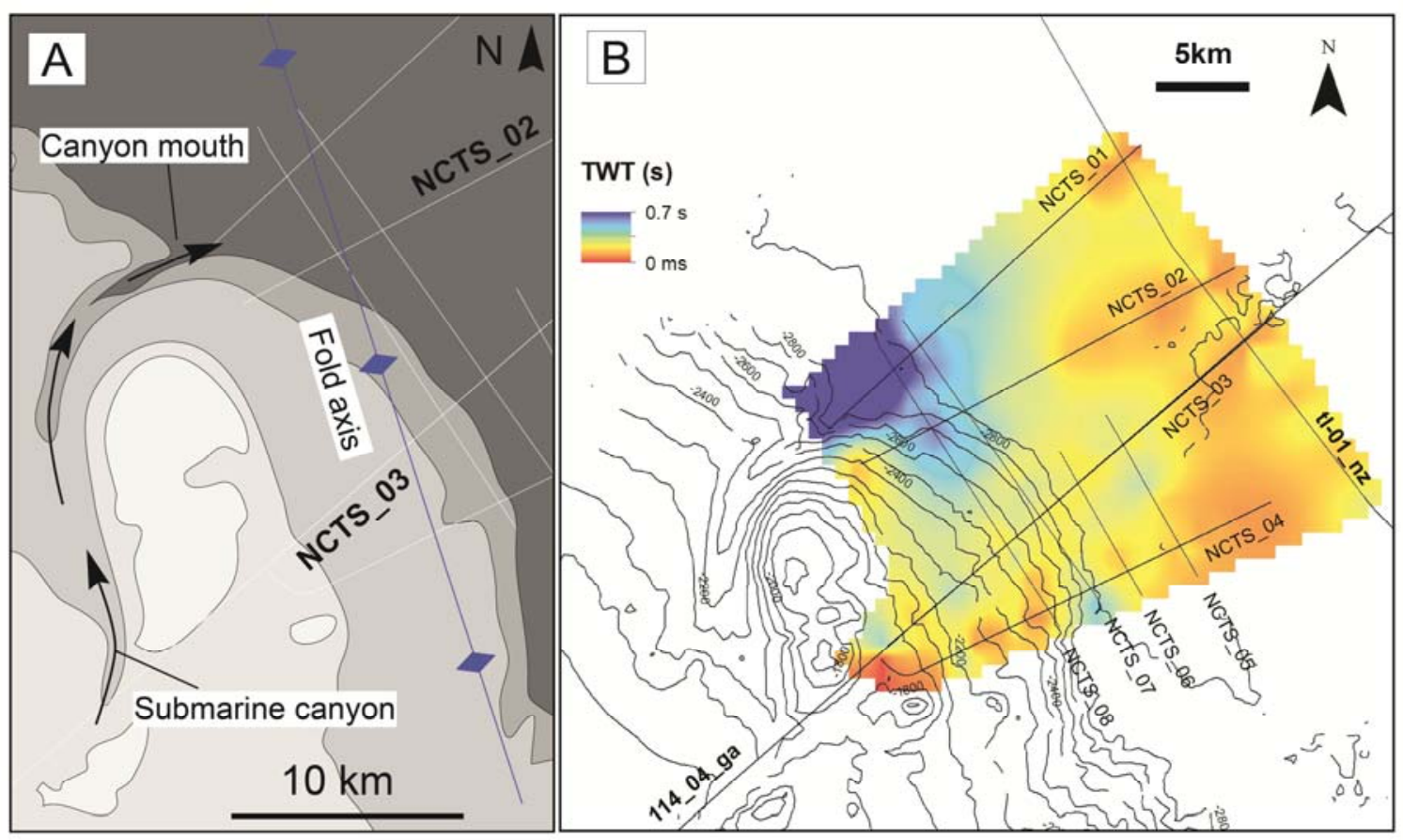

Figure 13: A. Schematic present day bathymetry map with direction of the main fold axis of Unit 2 strata and talweg of the present day submarine canyon. B. Thickness (second twt) interpolation map of Unit 1b over the TAN1409 seismic grid (flex gridding interpolation) with 100m isobathymetric contours. Maximum thickness is reached at the mouth of the canyon and progressively decreases in the downslope and alongslope directions, forming an overall lobe-shaped depocenter. This might suggests a genetic link between Unit $1 \mathrm{~b}$ and canyon-related deposition, either as mass-wasting events during canyon inception or as a canyon-mouth depositional lobe. 


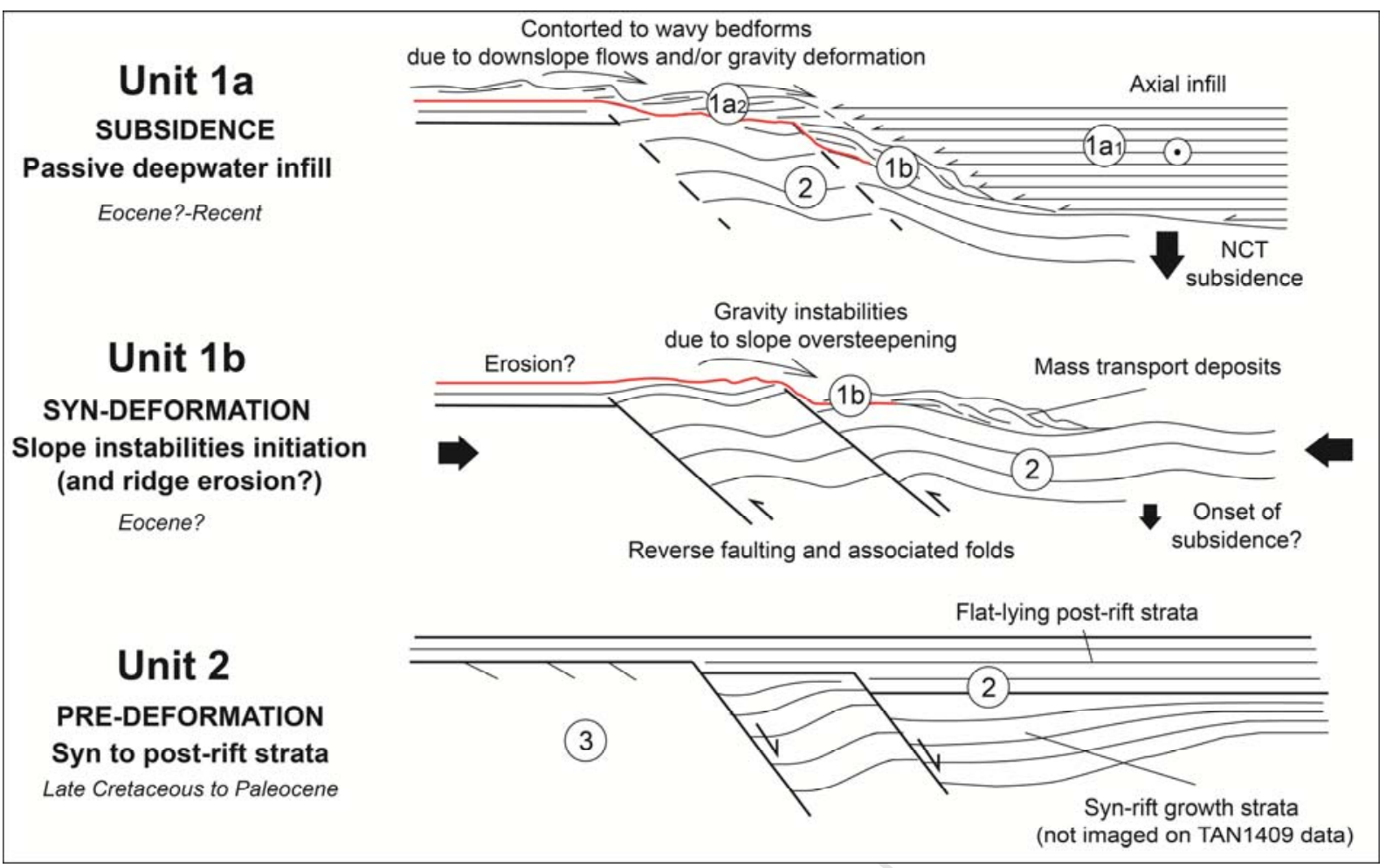

Figure 14: B. Conceptual summary cartoon explaining the stratigraphic relationships and possible origins of the unit and subunit differentiated in this study. 